\title{
Estimation of surface energy fluxes in the Arctic tundra using the remote sensing thermal-based Two-Source Energy Balance model
}

\author{
Jordi Cristóbal ${ }^{1,2}$, Anupma Prakash ${ }^{1}$, Martha C. Anderson ${ }^{3}$, William P. Kustas ${ }^{3}$, Eugénie S. Euskirchen ${ }^{4}$, and \\ Douglas L. Kane ${ }^{2}$ \\ ${ }^{1}$ Geophysical Institute, University of Alaska Fairbanks, Fairbanks, Alaska 99775, USA \\ ${ }^{2}$ Institute of Northern Engineering, Water Environmental Research Center, University of Alaska Fairbanks, \\ Fairbanks, Alaska 99775, USA \\ ${ }^{3}$ Hydrology and Remote Sensing Laboratory, United States Department of Agriculture, Agriculture Research Service, \\ Beltsville, Maryland 20705, USA \\ ${ }^{4}$ Institute of Arctic Biology. University of Alaska Fairbanks, Fairbanks, Alaska 99775, USA \\ Correspondence to: Jordi Cristóbal (j.cristobal@alaska.edu)
}

Received: 24 May 2016 - Discussion started: 21 June 2016

Revised: 27 January 2017 - Accepted: 7 February 2017 - Published: 7 March 2017

\begin{abstract}
The Arctic has become generally a warmer place over the past decades leading to earlier snow melt, permafrost degradation and changing plant communities. Increases in precipitation and local evaporation in the Arctic, known as the acceleration components of the hydrologic cycle, coupled with land cover changes, have resulted in significant changes in the regional surface energy budget. Quantifying spatiotemporal trends in surface energy flux partitioning is key to forecasting ecological responses to changing climate conditions in the Arctic. An extensive local evaluation of the Two-Source Energy Balance model (TSEB) - a remotesensing-based model using thermal infrared retrievals of land surface temperature - was performed using tower measurements collected over different tundra types in Alaska in all sky conditions over the full growing season from 2008 to 2012. Based on comparisons with flux tower observations, refinements in the original TSEB net radiation, soil heat flux and canopy transpiration parameterizations were identified for Arctic tundra. In particular, a revised method for estimating soil heat flux based on relationships with soil temperature was developed, resulting in significantly improved performance. These refinements result in mean turbulent flux errors generally less than $50 \mathrm{~W} \mathrm{~m}^{-2}$ at half-hourly time steps, similar to errors typically reported in surface energy balance modeling studies conducted in more temperate climatic regimes. The MODIS leaf area index (LAI) remote sensing product proved to be useful for estimating energy fluxes in
\end{abstract}

Arctic tundra in the absence of field data on the local biomass amount. Model refinements found in this work at the local scale build toward a regional implementation of the TSEB model over Arctic tundra ecosystems, using thermal satellite remote sensing to assess response of surface fluxes to changing vegetation and climate conditions.

\section{Introduction}

Air temperatures in the Alaskan Arctic have shown a significant increase, especially in past decade (Serreze and Barry, 2011). Results from models forced with a range of climate scenarios from the Intergovernmental Panel on Climate Change (IPCC) indicate that by the mid-21st century the permafrost area in the Northern Hemisphere is likely to decrease by $37-81 \%$ (IPCC, 2014). In general, the Arctic has become a warmer place, leading to an acceleration of the hydrologic cycle, earlier snow melt and drier soils due to permafrost degradation (AMAP, 2012; Elmendorf et al., 2012; Rawlins et al., 2010; Sturm et al., 2001; Overduin and Kane, 2006). Furthermore, the hydrologic response of the Arctic land surface to changing climate is dynamically coupled to the region's surface energy balance (Vörösmarty et al., 2001), and the partitioning of energy fluxes plays an important role in modulating the hydrologic cycle of Arctic basins (Rawlins et al., 2010). 
Evapotranspiration (ET, in units of mass, $\mathrm{kg} \mathrm{s}^{-1} \mathrm{~m}^{-2}$ or $\mathrm{mm} \mathrm{d}^{-1}$ ) or equivalently, latent heat flux (LE, in energy units, $\mathrm{W} \mathrm{m}^{-2}$ ), is an important component of both the land surface hydrologic cycle and surface energy balance. As an example, Kane et al. (2004) reported water loss due to ET in the Imnavait Creek basin in Alaska is about $74 \%$ of summer precipitation or $50 \%$ of annual precipitation, as estimated from water balance computations. Even though ET is a significant component of the hydrologic cycle in Arctic regions, it is poorly quantified in Arctic basins, and the bulk estimates do not accurately account for spatial and temporal variability due to vegetation type and topography (Kane et al., 2000). In the Arctic, values of ET or LE are usually either derived from field estimates (Kane et al., 1990; Mendez et al., 1998) or calculated purely from empirical or quasi-physical models such as those described by Zhang et al. (2000) and Shutov et al. (2006) using meteorological station forcing data. However, due to remoteness, harsh winter conditions and the high costs of maintaining ground-based measurement networks, the data currently collected are also both temporally and spatially sparse.

In Arctic tundra ecosystems, several factors have contributed to the vegetation change, such as increased extent of severe fires, increased extent in deciduous vegetation or shrub encroachment in tundra ecosystems (Myers-Smith et al., 2011; Sturm et al., 2001), among others. Over at least the past three decades, Arctic ecosystems have shown evidence of "greening" (Xu et al., 2013; Bhatt et al., 2010), with about a $17 \%$ increase in peak vegetation greenness for the Arctic tundra biome (Jia et al., 2003). Moreover, the forest-tundra transition zone is observed to be moving further north, tree heights are increasing and shrubs are becoming denser and taller (ACIA, 2004; AMAP, 2012). These changes in vegetation will have an important impact on the surface energy balance, especially in areas where shrubs have made their appearance in former tundra vegetation. This increase in leaf area index (LAI), together with canopy height and changes in the distribution of canopy elements, will augment the multiple scattering and absorption of radiation, likely resulting in a lower albedo (Beringer et al., 2005), although more detailed observations and measurements, particularly for the beginning of the snow-free period and peak growing season, are needed (Williamson et al., 2016). Also, according to Beringer et al. (2005), Bowen ratio increases from tundra to forested sites will result in an increasing dominance of sensible heat $(H)$ as the primary energy source heating the atmosphere. In the case of a transition from tundra to tall shrub and then to forest, $H$ would likely increase during the growing season from $\sim 15$ to nearly $30 \%$, respectively. This will have an important impact in the tundra energy partitioning, resulting in a positive feedback to the atmosphere that further warms the Arctic climate. However, the magnitude of changes in surface energy partitioning due to vegetation changes and resulting impact on local Arctic climate is still unclear and more research is needed to better under- stand these vegetation-change-atmosphere dynamics (Eugster et al., 2000; Jung et al., 2010).

In the last two decades, surface energy balance methods have demonstrated their utility in modeling water availability using diagnostic retrievals of energy fluxes from in situ or remote sensing data, especially data acquired in the thermal infrared (TIR) region (Kalma et al., 2008). While remote sensing estimates of ET over the Arctic exist from global modeling systems (Mu et al., 2009; Zhang et al., 2010), these modeling systems typically do not compute the full energy balance. To estimate energy fluxes at local scales, on the order of hundreds of meters, initiatives such as FLUXNET (http://fluxnet.ornl.gov/) provide eddy covariance flux measurements at discrete sites situated in different ecosystems across the US and globally. Unfortunately, there are few measurements sites in the Arctic (Mu et al., 2009), making the existing instrument network insufficient to capture pertinent details of the changing Arctic climate and landscape (ACIA, 2004; AMAP, 2012; Serreze and Barry, 2011; Vörösmarty et al., 2001). Detailed process-based (prognostic) land surface models can be also used to estimate coupled water and energy fluxes over landscapes (Duursma and Medlyn, 2012; Ek et al., 2003; Falge et al., 2005; Haverd et al., 2013; Smith et al., 2001; Vinukollu et al., 2012, among others); however, they may neglect important processes that are not known a priori. For example, Hain et al. (2015) demonstrated the value of comparing prognostic and TIR-based diagnostic latent heat flux estimates over the continental US to diagnose moisture sources and sinks that were not well-represented in the prognostic modeling system.

Given the critical need to better understand the water and energy balance over tundra ecosystems, and the role of changing climate and vegetation cover in driving these budgets, the aim of this work is to evaluate and refine a diagnostic TIR remote-sensing-based model for estimating seasonal dynamics of surface energy fluxes (LE, $H$, net radiation $\left(R_{\mathrm{n}}\right)$ and soil heat flux $\left.(G)\right)$ as well as energy partitioning in the Arctic tundra growing season from 2008 to 2012. Specifically, a refined version of the Two-Source Energy Balance model (TSEB; Norman et al., 1995) for Arctic tundra is evaluated with in situ forcing data from three eddy covariance flux towers in all sky conditions, and remote sensing estimates of vegetation properties (LAI, NDVI (normalized difference vegetation index) and EVI (enhanced vegetation index)) from the Moderate Resolution Imaging Spectroradiometer (MODIS). Model refinements include a new $G$ parameterization and new configurations to retrieve $R_{\mathrm{n}}$ (effective atmospheric emissivity), $H$ and LE (two different Priestley-Taylor configurations). The TSEB serves as the land surface scheme in a regional Atmosphere-Land Exchange Inverse (ALEXI) modeling system (Anderson et al., 2011), implemented operationally over North America as part of NOAA's GOES Evapotranspiration and Drought Information System. Although the TSEB has been demonstrated to work well over a range of vegetation and climate 
conditions at midlatitudes (Anderson et al., 2007, 2011; Choi et al., 2009; Sánchez et al., 2009; Tang, et al., 2011; Timmermans et al., 2007, among others), it has not yet been examined for tundra ecosystems characteristic of high latitudes.

\section{Two-Source Energy Balance model: an overview}

Evapotranspiration (ET) can be estimated by surface energy balance models that partition the energy available at the land surface $\left(R_{\mathrm{n}}-G\right.$, where $R_{\mathrm{n}}$ is net radiation and $G$ is the soil heat flux, both in $\left.\mathrm{W} \mathrm{m}^{-2}\right)$ into turbulent fluxes of sensible and latent heating ( $H$ and $\mathrm{LE}$, respectively, in $\mathrm{W} \mathrm{m}^{-2}$ ):

$\mathrm{LE}+H=R_{\mathrm{n}}-G$,

where $L$ is the latent heat of vaporization $\left(\mathrm{J} \mathrm{kg}^{-1}\right)$ and $E$ is ET $\left(\mathrm{kg} \mathrm{s}^{-1} \mathrm{~m}^{-2}\right.$ or $\left.\mathrm{mm} \mathrm{s}^{-1}\right)$.

The model used in this study is the series version of the TSEB scheme originally proposed by Norman et al. (1995), which has been revised to improve shortwave and longwave radiation exchange within the soil-canopy system and the soil-canopy energy exchange (Kustas and Norman, 1999, 2000). A list of the TSEB inputs can be found in Table 1 . TSEB has been successfully applied over rain-fed and irrigated crops and grasslands in temperate and semi-arid climates (Anderson et al., 2004, 2012; Cammalleri et al., 2010, 2012) but has not been previously applied over the Arctic tundra.

In the TSEB, directional surface radiometric temperature derived from satellite or a ground-based radiometer, $T_{\mathrm{RAD}}(\theta)$ $(\mathrm{K})$, is considered to be a composite of the soil and canopy temperatures, expressed as

$T_{\mathrm{RAD}}(\theta) \approx\left[f_{\mathrm{c}}(\theta) T_{\mathrm{c}}^{4}+\left(1-f_{\mathrm{c}}\right) T_{\mathrm{s}}^{4}\right]^{1 / 4}$,

where $T_{\mathrm{c}}$ is canopy temperature $(\mathrm{K}), T_{\mathrm{S}}$ is soil temperature $(\mathrm{K})$ and $f_{\mathrm{c}}(\theta)$ is the fractional vegetation cover observed at the radiometer view angle $\theta$. For a canopy with a spherical leaf angle distribution and LAI, $f_{\mathrm{c}}(\theta)$ can be estimated as

$f_{\mathrm{c}}(\theta)=1-\exp \left(\frac{-0.5 \Omega \mathrm{LAI}}{\cos \theta}\right)$,

where the factor $\Omega$ indicates the degree to which vegetation is clumped as in row crops or sparsely vegetated shrubland canopies (Kustas and Norman, 1999, 2000). The composite soil and canopy temperatures are used to compute the surface energy balance for the canopy and soil components of the combined land surface system:

$R_{N_{\mathrm{s}}}=H_{\mathrm{s}}+\mathrm{LE}_{\mathrm{s}}+G$,

$R_{N_{\mathrm{c}}}=H_{\mathrm{c}}+\mathrm{LE}_{\mathrm{c}}$,

where $R_{N_{\mathrm{s}}}$ is net radiation at the soil surface, $R_{N_{\mathrm{c}}}$ is net radiation divergence in the vegetated canopy layer, $H_{\mathrm{c}}$ and $H_{\mathrm{s}}$ are canopy and soil sensible heat flux, respectively, $\mathrm{LE}_{\mathrm{c}}$ is the canopy transpiration rate, $\mathrm{LE}_{\mathrm{S}}$ is soil evaporation and $G$ is the soil heat flux. The net shortwave radiation is calculated from the measured incoming solar radiation and the surface albedo, while net longwave radiation is estimated from the observed air and land surface temperatures, using the StefanBoltzmann equation with atmospheric emissivity from the Brutsaert (1975) method.

By permitting the soil and vegetated canopy fluxes to interact with each other, Norman et al. (1995) derived expressions for $H_{\mathrm{s}}$ and $H_{\mathrm{c}}$ expressed as a function of temperature differences where

$H_{\mathrm{s}}=\rho C_{\mathrm{p}} \frac{T_{\mathrm{s}}-T_{A_{\mathrm{c}}}}{r_{\mathrm{s}}}$,

and

$H_{\mathrm{c}}=\rho C_{\mathrm{p}} \frac{T_{\mathrm{c}}-T_{A_{\mathrm{c}}}}{r_{X}}$,

with the total sensible heat flux $H=H_{\mathrm{c}}+H_{\mathrm{s}}$ expressed as

$H=\rho C_{\mathrm{p}} \frac{T_{A_{\mathrm{c}}}-T_{\mathrm{a}}}{r_{\mathrm{a}}}$,

where $\rho$ is air density $\left(\mathrm{kg} \mathrm{m}^{-3}\right), C_{\mathrm{p}}$ is the specific heat of air $\left(\mathrm{kJ} \mathrm{kg}^{-1} \mathrm{~K}^{-1}\right), T_{A_{\mathrm{c}}}$ is air temperature in the canopy air layer $(\mathrm{K}), T_{\mathrm{a}}$ is the air temperature in the surface layer measured at some height above the canopy $(\mathrm{K}), r_{X}$ is the total boundary layer resistance of the complete canopy of leaves $\left(\mathrm{s} \mathrm{m}^{-1}\right), r_{\mathrm{s}}$ is the resistance to sensible heat exchange from the soil surface $\left(\mathrm{s} \mathrm{m}^{-1}\right)$ and $r_{\mathrm{a}}$ is aerodynamic resistance $\left(\mathrm{s} \mathrm{m}^{-1}\right)$ defined by

$R_{\mathrm{a}}=\frac{\left[\ln \left(\left(z_{\mathrm{u}}-d_{\mathrm{o}}\right) / z_{\mathrm{om}}\right)-\Psi_{M}\right]\left[\ln \left(\left(z_{T}-d_{\mathrm{o}}\right) / z_{\mathrm{om}}\right)-\Psi_{H}\right]}{k^{2} u}$.

In Eq. (9), $d_{\mathrm{o}}$ is the displacement height, $u$ is the wind speed measured at height $z_{\mathrm{u}}, k$ is von Karman's constant $(\approx 0.4)$, $z_{T}$ is the height of the $T_{\mathrm{a}}$ measurement, $\Psi_{\mathrm{M}}$ and $\Psi_{H}$ are the Monin-Obukhov stability functions for momentum and heat, respectively, and $z_{\mathrm{om}}$ is the aerodynamic roughness length.

The original resistance formulations are described in more detail in Norman et al. (1995) with revisions described in Kustas and Norman $(1999,2000)$. Weighting of the heat flux contributions from the canopy and soil components is performed indirectly by the partitioning of the $R_{\mathrm{n}}$ between soil and canopy and via the impact on resistance values from the fractional amount and type of canopy cover (see Kustas and Norman, 1999).

For the latent heat flux from the canopy, the PriestleyTaylor formula is used to initially estimate a potential rate for $\mathrm{LE}_{\mathrm{c}}$ :

$\mathrm{LE}_{\mathrm{c}}=\alpha_{\mathrm{PTC}} f_{\mathrm{g}} \frac{\Delta}{\Delta+\gamma} R_{N_{\mathrm{c}}}$,

where $\alpha_{\text {PTC }}$ is a variable quantity related to the PriestleyTaylor coefficient (Priestley and Taylor, 1972), but in this 
Table 1. Flux station name and location, period of model evaluation and list of inputs required by the TSEB. Average and standard deviation for the input values were computed for the full period of model evaluation for each site.

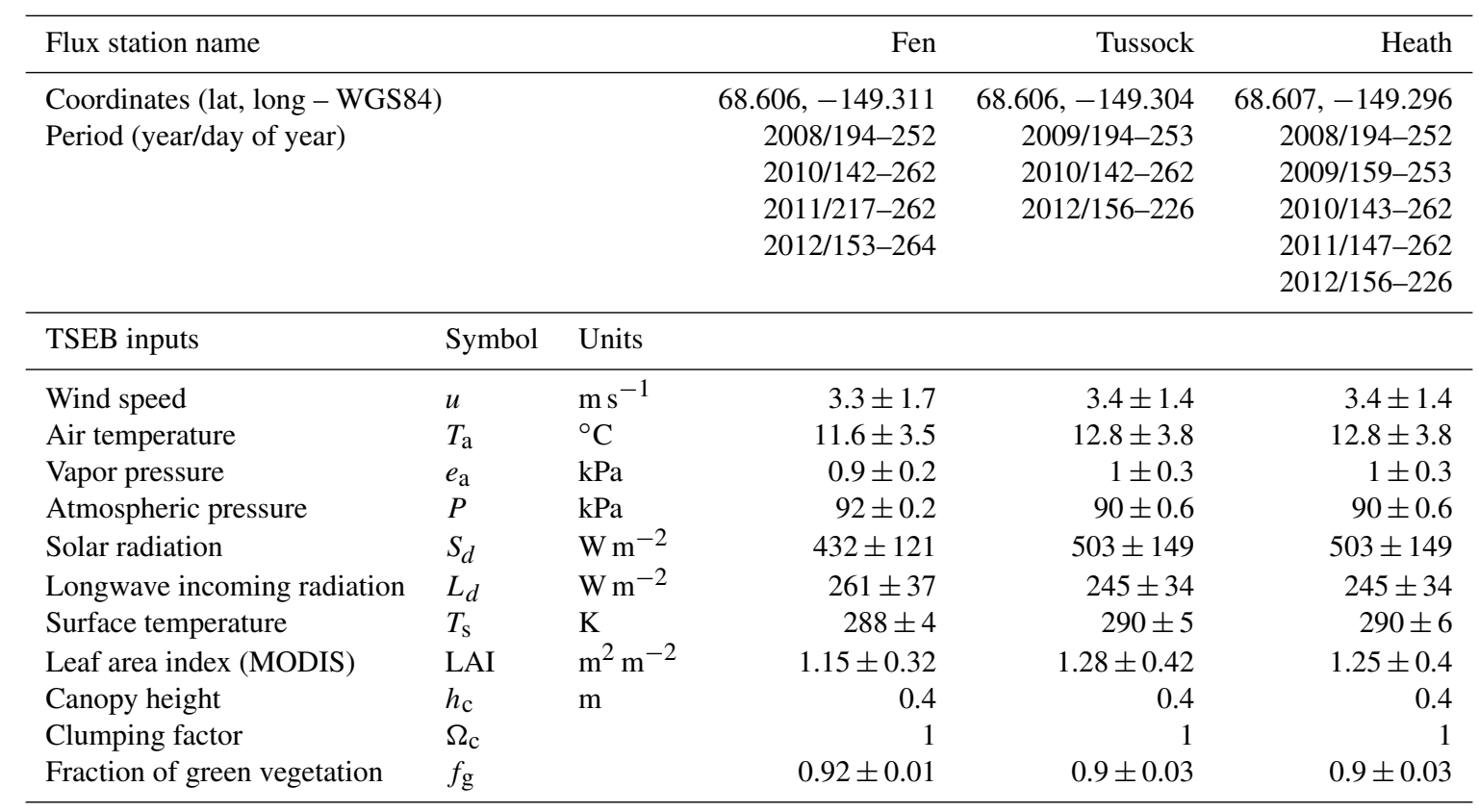

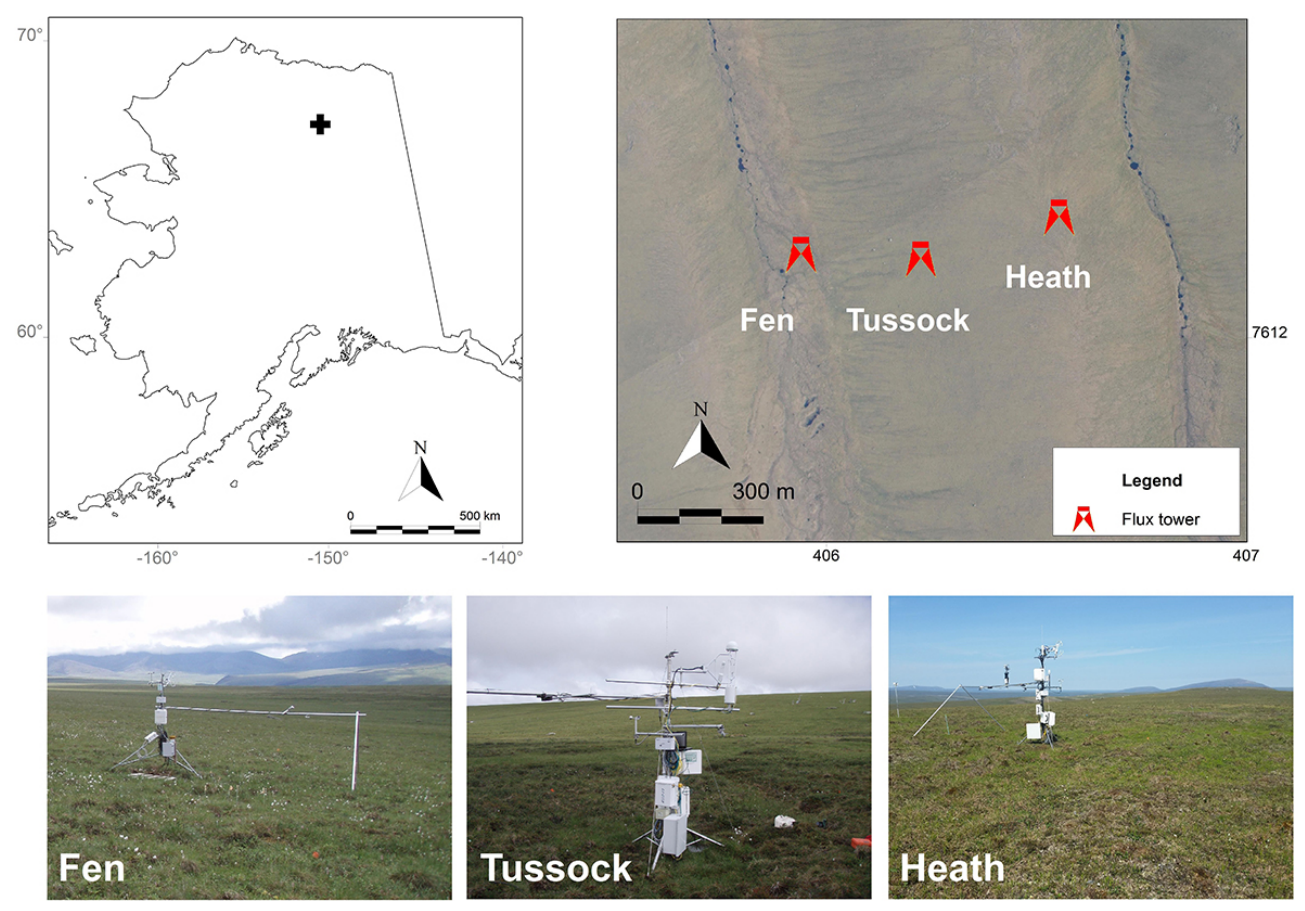

Figure 1. Location of the Fen, Tussock and Heath flux towers at the Imnavait watershed. Right panel map is in UTM-6N NAD83 with coordinates in kilometers.

case defined exclusively for the canopy component, which was suggested for row crops by Tanner and Jury (1976) and normally set to an initial value of $1.2, \Delta$ is the slope of the saturation vapor pressure versus temperature curve and $\gamma$ is the psychrometric constant $\left(\sim 0.066 \mathrm{kPa}^{\circ} \mathrm{C}^{-1}\right) . f_{\mathrm{g}}$ is the fraction of green vegetation that according to Guzinski et al. (2013) and Fisher et al. (2008) can be estimated through the NDVI and the EVI:

$$
f_{\mathrm{g}}=1.2 \frac{\mathrm{EVI}}{\mathrm{NDVI}}, 0 \leq f_{\mathrm{g}} \leq 1
$$


Under stress conditions, TSEB iteratively reduces $\alpha_{\mathrm{PTC}}$ from its initial value. The TSEB model requires both a solution to the radiative temperature partitioning (Eq. 2) and the energy balance (Eqs. 6 and 7), with physically plausible model solutions for soil and vegetation temperatures and fluxes. Nonphysical solutions, such as daytime condensation at the soil surface (i.e., $\mathrm{LE}_{\mathrm{s}}<0$ ), can be obtained under conditions of moisture deficiency. This happens because $\mathrm{LE}_{\mathrm{c}}$ is overestimated in these cases by the Priestley-Taylor parameterization, which describes potential transpiration. The higher $\mathrm{LE}_{\mathrm{c}}$ leads to a cooler $T_{\mathrm{c}}$ and $T_{\mathrm{S}}$ must be accordingly larger to satisfy Eq. (7). This drives $H_{\mathrm{s}}$ higher, and the residual $\mathrm{LE}_{\mathrm{s}}$ from Eq. (12) can become negative. If this condition is encountered by the TSEB scheme, $\alpha_{\text {PTC }}$ is iteratively reduced until $\mathrm{LE}_{\mathrm{S}} \sim 0$ (expected for a dry soil/substrate surface). However, there are instances where the vegetation is not transpiring at the potential rate but is not stressed due to its adaption to water and climate conditions (Agam et al., 2010) or the fact that not all the vegetation is green or actively transpiring (Guzinski et al., 2013) (a thorough discussion of conditions that force a reduction in $\alpha_{\mathrm{PTC}}$, can be also found in Anderson et al., 2005 and Li et al., 2005).

The latent heat flux from the soil surface is solved as a residual in the energy balance equation:

$\mathrm{LE}_{\mathrm{s}}=R_{N_{\mathrm{s}}}-G-H_{\mathrm{s}}$,

with $G$ estimated as a fraction of the net radiation at the soil surface $\left(c_{G}\right)$ :

$G=c_{G} R_{N_{\mathrm{s}}}$.

During the midmorning to midday period, the value of $c_{G}$ can be typically assumed to be constant (Kustas and Daughtry, 1990; Santanello and Friedl, 2003). In this case, a typical value of $\sim 0.3$ can be assumed for $c_{G}$ based on experimental data from several sources (Daughtry et al., 1990). However, $c_{G}$ value varies with soil type and moisture conditions as well as time, due to the phase shift between $G$ and $R_{N_{\mathrm{s}}}$ over a diurnal cycle (Santanello and Friedl, 2003).

\section{TSEB formulation refinements for Arctic tundra}

\subsection{Downwelling longwave radiation estimation: effective atmospheric emissivity for all sky conditions}

The original TSEB formulation estimates the downwelling longwave radiation component of $R_{\mathrm{n}}$ using the effective atmospheric emissivity $(\varepsilon)$ method described in Brutsaert (1975) for clear sky conditions:

$\varepsilon=C\left(e / T_{\mathrm{a}}\right)^{1 / 7}$,

where $e$ is the water pressure in millibars and $T_{\mathrm{a}}$ in $\mathrm{K}$, and $C$ is 1.24 as in the original Brutsaert (1975) formulation.
However, in this study, TSEB is applied for all sky conditions, including clear sky, partially cloudy and overcast conditions. To estimate $\varepsilon$ for all sky conditions, Crawford and Duchon (1999) proposed a methodology that incorporated the Brutsaert (1975) clear sky parameterization and the Deardorff (1978) cloudiness correction using a simple cloud modification introducing a cloud fraction term (clf) according to the following equation:

$\varepsilon=\left\{\operatorname{clf}+(1-\mathrm{clf})\left[C\left(e / T_{\mathrm{a}}\right)^{1 / 7}\right]\right\}$.

The clf is defined as

$\mathrm{clf}=1-s$,

where $s$ is the ratio of the measured solar irradiance to the clear sky irradiance. Shortwave clear sky irradiance used in Eq. (16) may be obtained through the methodology proposed by Pons and Ninyerola (2008), where incident clear sky irradiance is calculated through a digital elevation model at a specific point during a particular day of the year, taking into account the position of the Sun, the angles of incidence, the projected shadows, the atmospheric extinction and the distance from the Earth to the Sun.

For Arctic areas, Jin et al. (2006) suggested an improved formulation of $C$ for clear sky conditions that can also be applied in Eq. (15) for all sky conditions, defined as

$C=0.0003\left(T_{\mathrm{a}}-273.16\right)^{2}-0.0079\left(T_{\mathrm{a}}-273.16\right)+1.2983$.

In order to evaluate if the Jin et al. (2006) method offered more accurate estimates of $\varepsilon$ for Arctic conditions, this method was compared to Brutsaert (1975) formulation used in TSEB in both cases for all sky conditions using Eq. (15).

\subsection{Refinements in soil heat flux parameterization: $c_{G}$ coefficient and definition of a new coefficient based on $T_{\text {RAD }}$}

In the Arctic tundra, the propagation of the thawing front in the soil active layer consumes a large proportion (around $18 \%$ ) of the energy input from the positive net radiation (Boike et al., 2008a; Rouse, 1984). Moreover, the presence of permafrost in tundra areas may contribute to the large tundra soil heat flux by creating a strong thermal gradient between the ground surface and depth, offsetting the influence of the highly insulative moss cover which would otherwise have been expected to reduce soil heat flux (Myers-Smith et al., 2011; Sturm et al., 2001). Therefore, previous formulations of soil heat flux used in TSEB applications, mainly representative of cropped and sparse-vegetated areas in the US, need to be adjusted and validated for Arctic tundra.

Currently there are several methodologies that allow estimating soil heat flux from tenths of centimeters to meters in depth in the Arctic tundra by using modeling or instrumentation at several depths (Lynch et al., 1999; Ekici et al., 2015; 
Jiang et al., 2015; Romanovsky et al., 1997; Yao et al., 2011; Zhuang et al., 2001; Hinzman et al., 1998). However, in this study, a simple approach based on the relationship between $G$ and $R_{N_{\mathrm{s}}}$ (Eq. 13) was used to estimate the soil heat flux in the near-surface soil layer (around $10 \mathrm{~cm}$ depth). This approach has less complexity and requires less input data than the methods mentioned above and allows estimating $G$ at regional scales.

In early TSEB implementation, a constant value of $c_{G}$ value around 0.3 was used to estimate $G$ for the midmorning to midday period (Eq. 13 based on findings by Kustas and Daughtry (1990) for US study sites. However, this assumption can result in significant errors if applied out of this time range. For diurnal hourly timescales, Kustas et al. (1998) developed a method to estimate $c_{G}$ based on time differences with the local solar noon quantified by a non-dimensional time parameter. Although this approach does not consider the phase shift between $G$ and $R_{N_{\mathrm{s}}}$ over a diurnal cycle, a phase shift was included in the model proposed by Santanello and Friedl (2003) in the following form:

$c_{G}=A \cos [2 \pi(t+S) / B]$,

where $A$ represents the maximum value of $c_{G}, B$ is chosen to minimize the deviation of $c_{G}$ from Eq. (13), $t$ is time in seconds relative to solar noon and $S$ is the phase shift between $G$ and $R_{N_{\mathrm{S}}}$ in seconds. Values fitted for $A, S$ and $B$ were 0.31 , 10800 and 74000 , respectively.

Although $c_{G}$ values for Arctic tundra were not found in the literature, several studies (Beringer et al., 2005; Eugster et al., 2000, 2005; Boike et al., 2008b; Eaton et al., 2001; Kodama et al., 2007; Langer et al., 2011; Soegaard et al., 2001; Westermann et al., 2009; Mendez et al., 1998; Lund et al., 2014) present the relationship between $R_{N_{\mathrm{s}}}$ and $G$ during the summer months in similar tundra areas. According to these studies, a mean value of 0.14 , as a maximum value of $c_{G}$ in Eq. (18), can be derived from different analyses of $R_{N_{\mathrm{s}}}$ and $G$ over the Arctic tundra.

An alternative parameterization for $G$ was suggested by Santanello and Friedl (2003) for several types of soils with crops and by Jacobsen and Hansen (1999) for Arctic tundra that links the soil heat flux to the diurnal variations in surface radiometric temperature. This approach can also be applied for Arctic tundra as follows:

$G=c_{\mathrm{TG}} T_{\mathrm{RAD}}$,

where $c_{\mathrm{TG}}$ is a coefficient that represents the relationship between the diurnal variation of $T_{\mathrm{RAD}}$ and $G$. For diurnal hourly timescales, $c_{\mathrm{TG}}$ can be also estimated using the phase shift proposed in Eq. (18), where, in this case, $S$ is the phase shift between $G$ and $T_{\mathrm{RAD}}$ in seconds. This new approach avoids using $R_{N_{\mathrm{s}}}$, which is more difficult to define in tundra systems given the influence of the surface moss layer above the mineral soil. Moreover, $A, S$ and $B$ in Eq. (18) can be fitted by using direct measurements of $T_{\mathrm{RAD}}$ from thermal field sensors, commonly available on flux towers (pyrgeometer), or thermal data from geostationary or polar satellites.

Thus, to evaluate soil heat flux for diurnal hourly timescales, the approaches of Kustas et al. (1998) and Santanello and Friedl (2003) were compared using the original $c_{G}$ value of 0.30 and a new value for Arctic tundra of 0.14 , both as maximum values of $c_{G}$ in Eq. (18). $A, B$ and $S$ values for the new $c_{\mathrm{TG}}$ approach were fitted and tested using an extended evaluation dataset and then compared to these radiation-based methods (see Sect. 4.2).

\subsection{Priestley-Taylor coefficient}

In the original TSEB formulation, the Priestley-Taylor approach for the canopy component of LE is used. In this case, $\alpha_{\text {PTC }}$ is normally set to an initial value of 1.26 for the general conditions tested during the growing season in rangelands and croplands. For stressed canopies, TSEB internally modifies $\alpha_{\text {PTC }}$ to yield reasonable partitioning between $\mathrm{LE}_{\mathrm{c}}$ and $\mathrm{LE}_{\mathrm{s}}$.

As with the $c_{G}$ coefficient, specific $\alpha_{\mathrm{PTC}}$ values for tundra were not found in the literature. Alternatively, measurements of bulk (soil plus canopy) for Arctic tundra systems are available (Beringer et al., 2005; Eaton et al., 2001; Eugster et al., 2005; Engstrom et al., 2002; Mendez et al., 1998; Lund et al., 2014), suggesting a mean value of around 0.92 . This bulk value might suggest that $\alpha_{\text {PTC }}$ could also be lower for Alaska tundra summer conditions. For natural vegetation, Agam et al. (2010) also suggested that a lower $\alpha_{\text {PTC }}$ value might yield better results. Therefore, for modeling purposes, two different values of $\alpha_{\text {PTC }}$ values, 0.92 and 1.26 , were applied to evaluate which nominal $\alpha_{\text {PTC }}$ input to TSEB was more appropriate for Arctic tundra.

\section{Study area and data description}

\subsection{Study area}

To refine and evaluate the TSEB model for Alaska's Arctic tundra summer conditions, three eddy covariance flux towers (referred to as Fen, Tussock and Heath; see Fig. 1) were selected. These are located across the Imnavait Watershed ( $~ 904$ ma.s.1.) with eddy covariance and associated meteorological data collection beginning in 2007 (Euskirchen et al., 2012; Kade et al., 2012). A brief description of instrumentation at the tower sites is provided in Table 2.

The Fen tower, located at the valley bottom in a wet sedge ecosystem, includes Eriophorum angustifolium and dwarf shrubs such as Betula nana and Salix spp., and vegetation types around the tower are comprised of $52 \%$ wet sedge and $47 \%$ tussock tundra. The Tussock tower, located at the midslope in a moist acidic tussock tundra ecosystem, is dominated by the tussock-forming sedge Eriophorum vaginatum, Sphagnum spp. and dwarf shrubs such as Betula nana and Salix spp. In this case, vegetation types around the flux tower 
Table 2. General overview of the Fen, Tussock and Heath flux sites instrumentation (more information is available at http://aon.iab.uaf. edu/imnavait). Apogee infrared radiometers were oriented $45^{\circ}$ off nadir at the three flux stations. Negative measurement of height indicate measurements of depth.

\begin{tabular}{lll}
\hline Instrument & Description & Height $(\mathrm{m})$ \\
\hline Campbell Sci. CSAT3 & Three-dimensional sonic anemometer & $2.18-3.18$ \\
LI-COR LI-7500 & Open-path infrared gas analyzer $\left(\mathrm{CO}_{2}\right.$ and $\left.\mathrm{H}_{2} \mathrm{O}\right)$ & $2.18-3.18$ \\
Vaisala HMP45C & Temperature and relative humidity probe & $1.93-2.82$ \\
Hukseflux HFP01SC & Self-calibrating soil heat flux plates (four per site) & -0.08 \\
Campbell Sci. TCAV & Type E thermocouple averaging soil temperature probes (two per site) & $-0.02-0.04$ \\
Campbell Sci. CS616 & Water content reflectometers (two per site) & -0.025 \\
LI-COR LI190SB & PAR sensor (incoming) & $2-3.6$ \\
LI-COR LI190SB & PAR sensor (outgoing) & 2 \\
Met One Ins. 014A & Wind speed sensor & $1.5-2.26$ \\
Kipp \& Zonen CMA6 & Pyranometer/albedometer & 2 \\
* Kipp \& Zonen CNR4 & Four-component net radiometer & 2 \\
Kipp \& Zonen NR-Lite & Net radiation & 2 \\
Apogee IRR-P & Infrared radiometer sensor & $1.5-3$ \\
\hline
\end{tabular}

An asterisk $\left({ }^{*}\right)$ indicates that this instrument is only available at the Tussock flux station. PAR indicates photosynthetically active radiation.

are $95 \%$ tussock tundra. The Heath tower sits atop a broad dry ridge at the top edge of the eastern watershed boundary in a heath tundra ecosystem dominated by dwarf shrubs and lichen. The vegetation here is $20 \%$ heath, but also included $72 \%$ tussock tundra, with the balance made up of sedge meadow and bare soil. Further detailed information about the study is provided in Euskirchen et al. (2012) and Trochim et al. (2016).

\subsection{Model inputs, evaluation datasets and metrics}

\subsubsection{Micrometeorological input data}

Data incorporated in this study spanned the period from May to September in 2008 to 2012. These included eddy covariance data for latent and sensible collected at $10 \mathrm{~Hz}$ and processed to $30 \mathrm{~min}$ means (described below) as well as meteorological data collected at 30 min intervals (Tables 1 and 2). These data, from under all sky conditions, were used to refine and evaluate the model performance (Table 1). This dataset was considered to be representative of the short Arctic tundra vegetative cycle from early growing to senescence as well as used to capture inter- and intra-annual vegetation dynamics.

Meteorological inputs for TSEB include wind speed, air temperature, vapor pressure, atmospheric pressure, longwave incoming radiation and solar radiation, all of which were collected at the three measurement sites (see Tables 1 and 2). The surface radiometric temperature $T_{\mathrm{RAD}}$ inputs were obtained from the pyrgeometer sensor at the Tussock station and from infrared radiometer sensors at both Fen and Heath stations.

\subsubsection{Remote sensing input data: vegetation properties}

In addition, TSEB also requires estimates of LAI and the fraction of vegetation that is green to specify $f_{\mathrm{c}}$ in Eq. (2) and to estimate $\mathrm{LE}_{\mathrm{c}}$ in Eq. (10). While in situ measurements of LAI were not available at the tower sites for the length of this study, the $500 \mathrm{~m}$ combined Terra/Aqua MODIS 4day LAI product (MCD15A3H) was available for the study area. This product has been successfully applied in other applications of the TSEB (Guzinski et al., 2013), where sites are considered homogeneous over several kilometers, and serves here as a proxy for local observations. The fraction of vegetation that is green $\left(f_{\mathrm{g}}\right)$ in Eq. (10) was estimated using NDVI and EVI from MODIS imagery using the daily $250 \mathrm{~m}$ reflectance product (MOD09GQ), and using the blue band in the daily $500 \mathrm{~m}$ reflectance product (MOD09GA) to correct for residual atmospheric effects, with negligible spatial artifacts. Because MODIS time series contains occasional lower-quality data, gaps from persistent clouds, cloud contamination and other gaps (Gao et al., 2008), a program for analyzing time series of remote sensing imagery, TIMESAT (Jönsson and Eklundh, 2004), was used to produce temporally smoothed NDVI, EVI and LAI by selecting the best estimates through these products' quality flags. Gao et al. (2008) found a good agreement with field measurements when smoothing MODIS LAI data using this distribution and several weights $(w)$ based on the product quality flags ( $w=1.0$ for LAI retrievals from the radiative-transfer model (high quality) or for LAI retrieval that reaches saturation, $w=0.25$ for retrievals from an empirical model and $w=0.0$ for all invalid and fill values). Beck et al. (2006) also reported that an asymmetric Gaussian distribution was appropriate for describing vegetation dynamics using NDVI at high latitudes and several weights $(w)$ based on the product 
Table 3. Performance statistics for the soil heat flux estimation using Santanello and Friedl (2003) (SF03) and Kustas et al. (1998) (K98) methodologies and two values for the maximum $c_{G}$ value. RMSE, MBE and MAD are in $\mathrm{W} \mathrm{m}^{-2}$ and MAPD is in $\%$.

\begin{tabular}{|c|c|c|c|c|c|c|c|c|c|c|c|c|}
\hline & \multirow[b]{2}{*}{$c_{G}$} & \multirow[b]{2}{*}{$n$} & \multicolumn{5}{|c|}{ SF03 } & \multicolumn{5}{|c|}{ K98 } \\
\hline & & & $R^{2}$ & RMSE & MBE & MAD & MAPD & $R^{2}$ & RMSE & MBE & MAD & MAPD \\
\hline \multirow[t]{2}{*}{ Fen } & 0.30 & 1558 & 0.04 & 23 & 3 & 20 & 128 & 0.01 & 40 & 23 & 31 & 199 \\
\hline & 0.14 & & 0.04 & 15 & -7 & 12 & 76 & 0.01 & 15 & 2 & 11 & 73 \\
\hline \multirow[t]{2}{*}{ Tussock } & 0.30 & 1273 & 0.18 & 23 & 3 & 18 & 78 & 0.05 & 39 & 21 & 32 & 138 \\
\hline & 0.14 & & 0.23 & 17 & -11 & 12 & 53 & 0.05 & 15 & -4 & 11 & 46 \\
\hline \multirow[t]{2}{*}{ Heath } & 0.30 & 2347 & 0.11 & 26 & -5 & 20 & 96 & 0.10 & 34 & 14 & 26 & 125 \\
\hline & 0.14 & & 0.14 & 21 & -14 & 15 & 72 & 0.06 & 16 & -5 & 10 & 48 \\
\hline \multirow[t]{2}{*}{ Total } & 0.30 & 5178 & 0.12 & 25 & 0 & 20 & 98 & 0.03 & 37 & 19 & 29 & 145 \\
\hline & 0.14 & & 0.10 & 18 & -11 & 14 & 68 & 0.03 & 15 & -3 & 11 & 53 \\
\hline
\end{tabular}

Table 4. Accuracy statistic for the new $c_{\mathrm{TG}}$ approach for the fit and the test. RMSE, MBE and MAD are in W m ${ }^{-2}$, MAPD is in $\%$ and $n$ is the number of half-hour intervals.

\begin{tabular}{|c|c|c|c|c|c|c|c|c|c|c|c|c|}
\hline & \multicolumn{4}{|c|}{ Fit subset $(60 \%)$} & \multicolumn{4}{|c|}{ Test subset $(40 \%)$} & \multicolumn{4}{|c|}{ Flux dataset } \\
\hline & Fen & Tussock & Heath & Total & Fen & Tussock & Heath & Total & Fen & Tussock & Heath & Total \\
\hline$R^{2}$ & 0.89 & 0.99 & 0.99 & 0.99 & 0.55 & 0.77 & 0.69 & 0.68 & 0.27 & 0.56 & 0.49 & 0.44 \\
\hline RMSE & 3.9 & 1 & 1 & 1 & 7 & 5 & 6 & 6 & 9 & 5 & 7 & 7 \\
\hline MBE & 1.7 & -0.2 & -0.6 & 0.1 & 0.6 & -0.3 & -0.3 & 0 & 3.9 & 0.5 & -0.3 & 1 \\
\hline MAD & 2.8 & 1 & 1 & 1 & 5 & 4 & 5 & 4 & 7 & 4 & 5 & 6 \\
\hline MAPD & 25 & 8 & 8 & 8 & 49 & 28 & 38 & 37 & 44 & 17 & 24 & 28 \\
\hline$n$ & 8283 & 10332 & 10748 & 29363 & 3310 & 4122 & 4273 & 11705 & 1558 & 1273 & 2347 & 5178 \\
\hline
\end{tabular}

quality flags (highest quality/clear, mixed and cloudy were assigned weights of 1, 0.5 and 0, respectively). For NDVI, EVI and LAI time series smoothing, the weights and quality flags proposed by Beck et al. (2006) and Gao et al. (2008) were used.

Vegetation height, used to define roughness parameters $d_{\mathrm{o}}$ and $z_{\mathrm{om}}$, was assigned based on measurements made in the vicinity of the flux towers (Kade et al., 2012), and the clumping factor was set to 1 for all sites based on the knowledge that Arctic tundra has a variable moss layer with little bare ground. Variability regarding these inputs for the studied periods is shown in Table 1. Moreover, to ensure that only snow-free periods were analyzed, Terra/Aqua MODIS snow cover products (MOD10A1 and MYD10A1) were used to screen days with snow cover at the beginning and end of the growing season.

\subsubsection{Micrometeorological flux data for model evaluation}

The eddy covariance data used in TSEB evaluation, including latent and sensible heat, were processed with EddyPro $^{\circledR}$ (2014) software. Changes in mass flow caused by changes in air density (Webb et al., 1980), corrections for frequency attenuation of eddy covariance fluxes following Massman (2000) and Rannik (2001) and storage corrections for calm periods (friction velocity $\left(u^{*}\right)$ was less than
$0.1 \mathrm{~m} \mathrm{~s}^{-1}$, as suggested by Rocha and Shaver, 2011) were accounted for. The automatic gain control (AGC) value (which represents optical impedance by precipitation) was computed for the infrared gas analyzer (IRGA) and used as a QA/QC variable for both flux and radiation data, with 60 as the maximum threshold value (LI-COR Inc, 2004). Rejection angles of $10^{\circ}$ were also used when the eddy covariance instruments were downwind of a tower to remove flow distortions. In addition, corrections for stationarity, lags and step change, among others, were performed by the flux processing software (for further information on micrometeorological data processing, see Euskirchen et al., 2012, and http: //aon.iab.uaf.edu/data_info). To select the best data available, the above criteria were used to flag the micrometeorological dataset, and no gap-filled data were used.

In addition, soil heat flux plate measurements were corrected to account for soil heat storage above the plate according to the calorimetric methodology proposed by Domingo et al. (2000) and Lund et al. (2014) using existing field measurements of soil bulk density for each site $(758,989$ and $1038 \mathrm{~kg} \mathrm{~m}^{-3}$ for Fen, Tussock and Heath flux stations, respectively), soil moisture from the water content reflectometer and thermocouple averaging soil temperature probes (TCAVs) placed at two depths in the soil (see Table 2).

To evaluate the new $c_{\text {TG }}$ approach, a total of 41068 halfhourly time steps of $T_{\mathrm{RAD}}$ and $G$ from 04:00 to 21:00 LST 
were selected (11 593, 14454 and 15021 for Fen, Tussock and Heath flux stations, respectively). Coefficients $A, B$ and $S$ were fitted using $60 \%$ of all available data (fitting subset) aggregated in $30 \mathrm{~min}$ time steps for the whole summer period. The remaining $40 \%$ of the data were reserved for model testing (test subset) (see Table 4 for flux stations distribution). To evaluate the TSEB model, including $G$ retrieve from Kustas et al. (1998) and Santanello and Friedl (2003) approaches, a total of 5178 half-hourly time steps $(1558,1273$ and 2347 for Fen, Tussock and Heath flux stations, respectively) were subset from the previous selection by imposing three criteria: (a) energy closure at the half-hourly timescale exceeded $70 \%$, (b) $R_{\mathrm{n}}$ was higher than $100 \mathrm{~W} \mathrm{~m}^{-2}$ in order to ensure daylight conditions and (c) no precipitation was present.

\subsubsection{Evaluation metrics}

For model evaluation, surface energy fluxes $\left(R_{\mathrm{n}}, \mathrm{LE}, H\right.$ and $G$ ) from the flux datasets (observed values) were compared to TSEB outputs (estimated values) using five metrics describing model errors and biases: the coefficient of determination $\left(R^{2}\right)$ was used to indicate the precision of the estimates in relation to observed surface energy fluxes; the root mean square error (RMSE) was used as a measure of accuracy to measure differences between values estimated by the TSEB model and values actually observed by the flux towers; the mean bias error (MBE) was used to indicate cumulative offsets between measured and observed values; the mean absolute difference (MAD) was used to indicate the magnitude of the average absolute difference of observed and estimated values; and finally, the mean absolute percent difference (MAPD) was used to express the magnitude of absolute difference between observed and estimated values relative to the observed mean value, from Eqs. (20) to (24), respectively.

$R^{2}=\left(\frac{\sum_{i=1}^{n}\left(o_{i}-\bar{O}\right)\left(e_{i}-\bar{E}\right)}{\sqrt{\sum_{i=1}^{n}\left(o_{i}-\bar{O}\right)^{2}} \sqrt{\sum_{i=1}^{n}\left(e_{i}-\bar{E}\right)^{2}}}\right)$,

$\mathrm{RMSE}=\sqrt{\frac{\sum_{i=1}^{n}\left(e_{i}-o_{i}\right)^{2}}{n}}$,

$\mathrm{MBE}=\frac{\sum_{i=1}^{n}\left(e_{i}-o_{i}\right)}{n}$,

$\mathrm{MAD}=\frac{\sum_{i=1}^{n}\left|e_{i}-o_{i}\right|}{n}$,

$\operatorname{MAPD}=\frac{100}{n}\left(\frac{\sum_{i=1}^{n}\left|e_{i}-o_{i}\right|}{\bar{O}}\right)$,

where $e_{i}$ refers to the estimated value of the variable in question $\left(R_{\mathrm{n}}, H, \mathrm{LE}\right.$ or $\left.G\right), o_{i}$ is the observed value (in situ measurement provided by the flux station), $n$ is the number of data points, and $\bar{O}$ and $\bar{E}$ are the average of the $o_{i}$ and $e_{i}$ values, respectively.

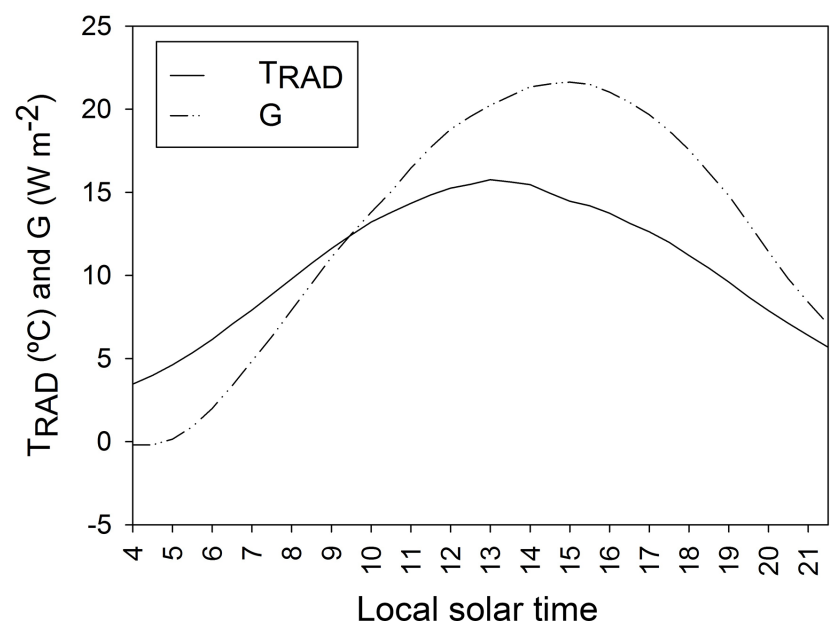

Figure 2. Mean daytime cycle for $G$ and $T_{\mathrm{RAD}}$ in the study area computed using all data available from the Fen, Tussock and Heath flux towers from 2008 to 2012.

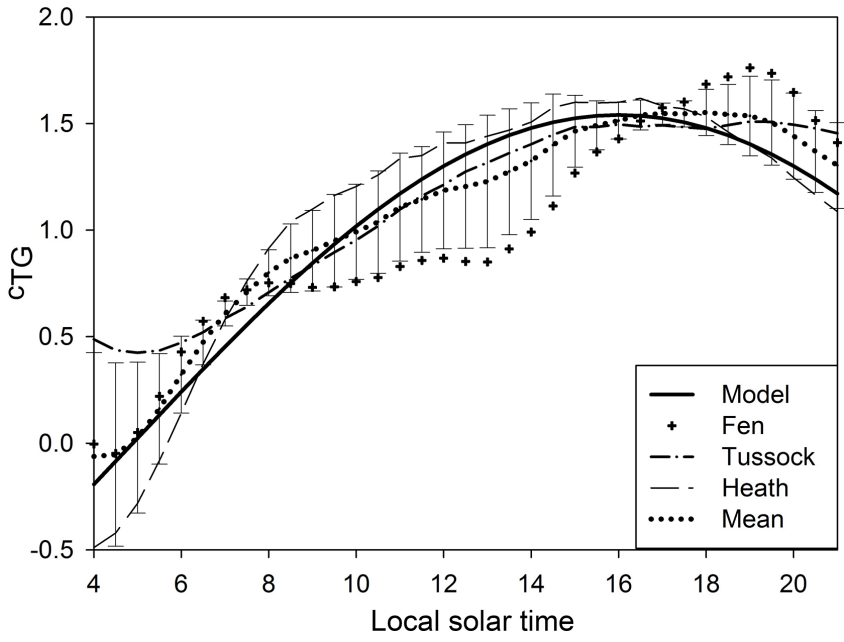

Figure 3. Time series of modeled $c_{\mathrm{TG}}$ and observed $c_{\mathrm{TG}}$ values from the Fen, Tussock and Heath flux stations as well as mean values for summer conditions (bars represent standard deviation of the mean).

\section{Results and discussion}

\subsection{Evaluation of soil heat flux model refinements for tundra}

Both the Kustas et al. (1998; K98) and the Santanello and Friedl (2003; SF03) soil heat flux models used to estimate $G$ at the study sites yielded high errors when a value of $c_{G}=0.3$ was used, with MAPD ranging from 90 to $159 \%$. In this case, the SF03 approach provided better results (Table 3). It is important to note that $G$ is a relatively small term with a maximum value on the order of $50 \mathrm{~W} \mathrm{~m}^{-2}$. Both models generally overestimated $G$ with a MBE from 3 to $40 \mathrm{~W} \mathrm{~m}^{-2}$, with the SF03 model generating lower biases. Results improved when 


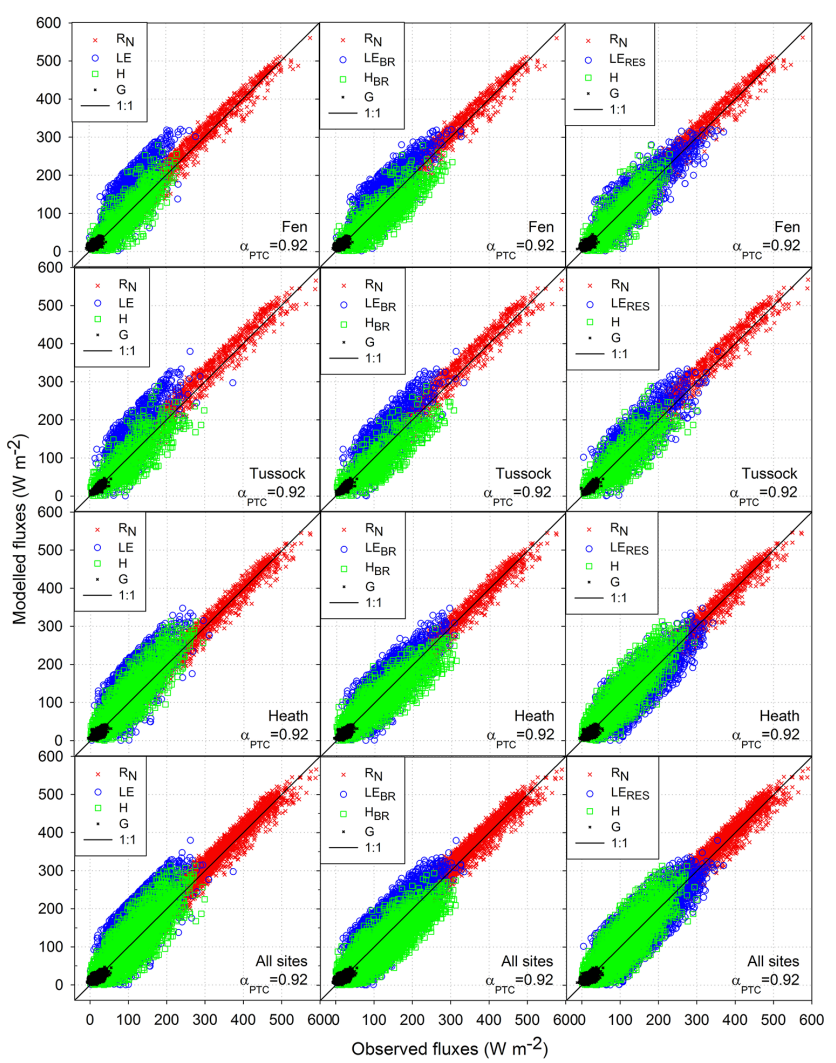

Figure 4. Comparison of modeled vs. measured half-hourly fluxes using $\alpha_{\text {PTC }}$ of 0.92 . The $1: 1$ line represents perfect agreement with observations. Columns represent results with unclosed observed turbulent fluxes (left), Bowen ratio closure (middle) and residual closure (right) for the Fen, Tussock, Heath sites and all sites combined (rows).

a $c_{G}$ value of 0.14 was used, with MAPD ranging from 48 to $76 \%$ and with lower RMSE values from 15 to $21 \mathrm{~W} \mathrm{~m}^{-2}$ and MBE from -4 to $-14 \mathrm{~W} \mathrm{~m}^{-2}$. With the lower value of $c_{G}$, the K98 approach provided better results (Table 3).

Similar to the original $c_{G}, c_{\mathrm{TG}}$ can be also estimated using the Santanello and Friedl (2003) method in Eq. (18). Mean diurnal profiles in $T_{\mathrm{RAD}}$ and $G$, averaged over all tundra sites (see Sect. 4.2 and Table 3) showed a phase shift between these variables (Fig. 2). The mean $G$ value for the summer period peaked around 15:00 LT, with a phase shift around $4 \mathrm{~h}$ after the maximum $T_{\mathrm{RAD}}$ at noon. Using $T_{\mathrm{RAD}}$ and $G$ observations at half-hourly time steps from the fitting subset, diurnal $c_{\mathrm{TG}}$ curves were derived for the growing season for each of the tower sites, showing reasonable agreement (Fig. 3). A fit to the mean curve yielded parameter values of $S=-14400 \mathrm{~s}, A=1.55$ and $B=160000 \mathrm{~s}$. As in the case of Santanello and Friedl (2003), a $B$ variation of $\pm 15000 \mathrm{~s}$ had no significant influence on the results. Statistical comparisons between observed fluxes from the test subset and simulations using the fitted parameters show good agreement and negligible bias (Table 4) with $R^{2}$, MAPD, RMSE and MBE values of $0.68,37 \%, 6$ and $0 \mathrm{~W} \mathrm{~m}^{-2}$, respectively. In addition, the new model was also evaluated using the same flux subset used in Table 3 to assess the K98 and SF03 configurations, demonstrating improved performance with roughly half the MAPD than K98 and SF03 configurations (Table 4).

The performance of the $G$ parameterization for Arctic tundra reported here is comparable or superior to previous studies reported in the literature using the Santanello and Friedl (2003) or Kustas et al. (1998) approaches for other ecosystems. In shrub-grass-dominated areas and boreal forest, several studies (Anderson et al., 2008; Kustas et al., 1998; Li et al., 2008; Sánchez et al., 2009; Timmermans et al., 2007) reported MAPD and RMSE values ranging from 19 to $59 \%$ and from 15 to $35 \mathrm{~W} \mathrm{~m}^{-2}$, respectively. Studies in corn and soybean crops (Anderson et al., 2005; Choi et al., 2009; Li et al., 2005; Santanello and Friedl, 2003) reported MAPD and RMSE values ranging from 19 to $34 \%$ and from 10 to $41 \mathrm{~W} \mathrm{~m}^{-2}$, respectively.

\subsection{Net radiation evaluation: effective atmospheric emissivity}

Effective atmospheric emissivity estimated using the Brutsaert (1975) and Jin et al. (2006) methodologies yielded similar errors in simulated downwelling longwave radiation results, with a $R^{2}$ of 0.58 and a RMSE of 26 and $27 \mathrm{~W} \mathrm{~m}^{-2}$, respectively. The $C$ coefficient computed through Jin et al. (2006) yielded a value of $1.25 \pm 0.009$, very close to Brutsaert (1975) $C$ value of 1.24. This suggests that the simpler Brutsaert (1975) $C$ coefficient can be used efficiently to model effective atmospheric emissivity in all sky conditions when combined with Crawford and Duchon (1999) and Pons and Ninyerola (2008) methods for summer Arctic tundra.

Estimated $R_{\mathrm{n}}$ for all sky conditions yielded strong agreement with observed values for all flux towers (see Fig. 4 and Table 5) with a mean $R^{2}$, MAPD, MAD and RMSE of 0.99 , $7 \%, 18 \mathrm{~W} \mathrm{~m}^{-2}$ and $23 \mathrm{~W} \mathrm{~m}^{-2}$, with a tendency to overestimate $R_{\mathrm{n}}$ with a MBE of $7 \mathrm{~W} \mathrm{~m}^{-2}$. In terms of RMSE and MAPD, all study sites behaved similarly (see Fig. 4). These results are in line with previous TSEB model applications for other cover types and clear sky conditions where a MAPD of around $5 \%$ was reported (Anderson et al., 2000, 2005, 2008; Li et al., 2005, 2008; Kustas and Norman, 1999; Guzinski et al., 2013). This suggest that $R_{\mathrm{n}}$ estimation using this scheme can be applied regionally under summer all sky conditions in Arctic tundra when a source of solar radiation (METEOSAT or GOES; Cristóbal and Anderson, 2013), air temperature (Cristóbal et al., 2008) and $T_{\mathrm{RAD}}$ (MODIS land surface temperature and emissivity product) are available.

\subsection{Latent and sensible heat fluxes evaluation: $\alpha_{\text {PTC }}$ configuration for Arctic tundra}

The average energy balance closure using half-hour periods for the evaluation dataset was $88 \%$, which is in agreement 
with the average closure of $90 \%$ for these flux stations (Euskirchen et al., 2012). Lack of closure may be explained by instrument and methodological uncertainties, insufficient estimation of storage terms, unmeasured advective fluxes, landscape-scale heterogeneity or instrument spatial representativeness, among others (Lund et al., 2014; Stoy et al., 2013; Foken et al., 2011; Foken, 2008; Wilson et al., 2001). More recently, there is evidence that non-orthogonal sonics underestimate vertical velocity causing undermeasurement of $H$ and LE on the order of $10 \%$ (Kochendorfer et al., 2012a; Frank et al., 2013), although this is still being debated (Kochendorfer et al., 2012b). While, currently, there is no uniform answer on how to deal with non-closure of the energy balance in eddy covariance datasets, and methods for analyzing the reasons for the lack of closure are still under discussion (Foken et al., 2011), in this study, TSEB output is primarily compared with eddy covariance fluxes as observed, without closure corrections. However, to facilitate comparisons to numerous studies in the literature imposing energy conservation to eddy covariance data when evaluating surface energy balance models (Courault et al., 2005; Kalma et al., 2008), and given that strong evidence is presented in the literature that both $H$ and LE are undermeasured by the eddy covariance technique, additional comparisons with closed fluxes using the Bowen ratio $\left(H_{\mathrm{BR}}\right.$ and $\left.\mathrm{LE}_{\mathrm{BR}}\right)$ approach suggested by Twine et al. (2000) and LE recalculated as the residual (LERES, e.g., Li et al., 2008) are provided for completeness. Results with closed fluxes are presented to provide bounds on the range in probable model performance and to demonstrate the impact of closure corrections on model evaluation metrics.

LE and $H$ estimated through both the new proposed soil heat flux methodology and the all sky $R_{\mathrm{n}}$ methodology scheme yielded reasonable agreement with observed halfhourly unclosed turbulent fluxes for both $\alpha_{\text {PTC }}$ parameterizations of 0.92 and 1.26 (see Tables 4 and 5, and Fig. 4), although $\alpha_{\text {PTC }}=0.92$ yielded marginally lower errors for $H$ and LE. Relative errors (MAPDs) were 40 and $25 \%$ for LE and $H$, respectively, for all combined sites using $\alpha_{\text {PTC }}=0.92$, and 45 and $27 \%$ using the standard value of $\alpha_{\mathrm{PTC}}=1.26$, respectively. A slight improvement in $H$ and LE estimates using $\alpha_{\text {PTC }} \sim 0.9$ also agrees with Agam et al. (2010) who also found better results with lower $\alpha_{\text {PTC }}$ for natural vegetation in water-limited environments.

When energy balance closure is imposed, model performance is mainly improved for LE (up to $10 \%$ decrease in MAPD) in part due to the fact that the measured turbulent fluxes are adjusted to achieve energy conservation as required by surface energy balance models. Indeed, the relatively small errors between modeled and measured $R_{\mathrm{n}}$ (Table 5) and relatively small and unbiased magnitude in modeled/measured $G$ (Table 5 and Fig. 4) suggest the unclosed turbulent fluxes contribute to the error statistics comparing Tables 5 and 6 with closed $H$ and LE observed fluxes.

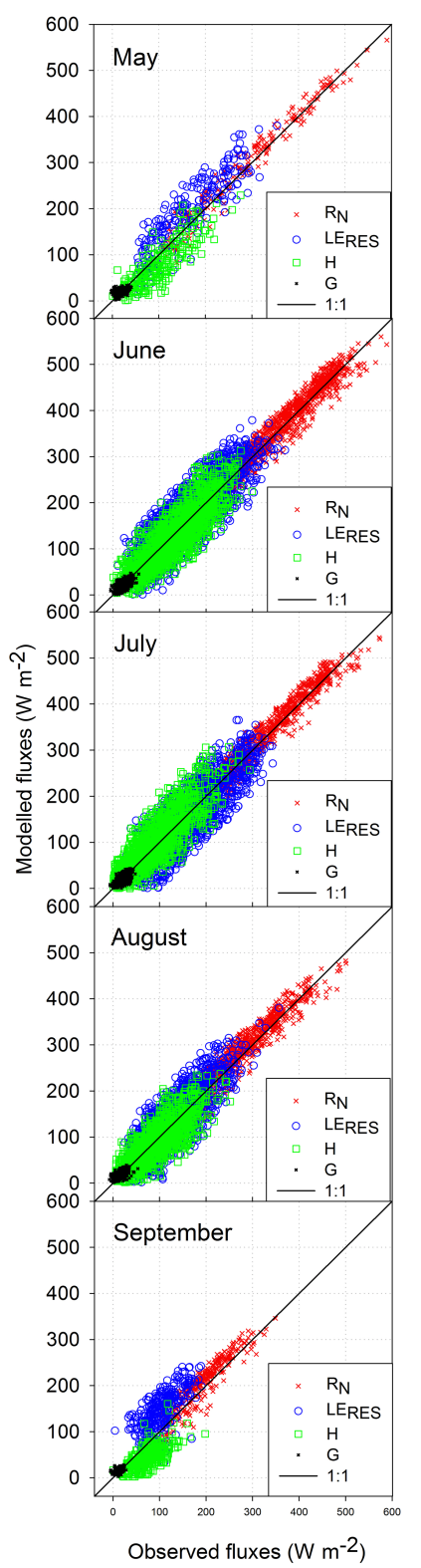

Figure 5. Comparison of modeled vs. observed half-hourly surface fluxes (using LE from residual closure) by month using $\alpha_{\text {PTC }}$ of 0.92 and $G$ estimated by the new model. The $1: 1$ line represents perfect agreement with observations.

Nevertheless, since the mean RMSE for all fluxes compared to unclosed and closed turbulent fluxes and for all parameterizations and sites was around $50 \mathrm{~W} \mathrm{~m}^{-2}$ (Tables 5 and 6 ), which is commensurate with errors typically reported in other surface energy balance studies (Kalma et al., 2008), these results suggest that a generalized $\alpha_{\text {PTC }}$ value of 1.26 in global TSEB applications may adequately reproduce energy fluxes in Arctic tundra during the growing season, from leafout until senescence, while also capturing inter- and intraannual dynamics. However, biases in regional applications 
Table 5. Accuracy and error statistics from the comparison of modeled vs. observed unclosed and closed surface fluxes using $\alpha_{\mathrm{PTC}}$ of 0.92 . $n$ is the number of half-hour periods analyzed. RMSE, MAD and MBE are in $\mathrm{W} \mathrm{m}^{-2}$ and MAPD is in $\%$.

\begin{tabular}{|c|c|c|c|c|c|c|c|c|c|c|c|c|c|}
\hline & & \multicolumn{5}{|c|}{$R_{\mathrm{n}}$} & & & \multicolumn{5}{|c|}{$\mathrm{LE}$} \\
\hline & $n$ & $R^{2}$ & RMSE & MBE & MAD & MAPD & & $n$ & $R^{2}$ & RMSE & MBE & MAD & MAPD \\
\hline Fen & 1558 & 0.99 & 23 & 8 & 18 & 7 & Fen & 1558 & 0.54 & 47 & 27 & 37 & 36 \\
\hline Tussock & 1273 & 0.99 & 25 & 12 & 19 & 7 & Tussock & 1273 & 0.52 & 61 & 44 & 51 & 41 \\
\hline Heath & 2347 & 0.99 & 20 & 2 & 15 & 6 & Heath & 2347 & 0.55 & 54 & 33 & 44 & 42 \\
\hline \multirow[t]{3}{*}{ Total } & 5178 & 0.99 & 23 & 7 & 18 & 7 & Total & 5178 & 0.54 & 53 & 35 & 44 & 40 \\
\hline & & \multicolumn{5}{|c|}{$\mathrm{LE}_{\mathrm{BR}}$} & & & \multicolumn{5}{|c|}{$\mathrm{LE}_{\mathrm{RES}}$} \\
\hline & $n$ & $R^{2}$ & RMSE & MBE & MAD & MAPD & & $n$ & $R^{2}$ & RMSE & MBE & MAD & MAPD \\
\hline Fen & 1558 & 0.76 & 45 & 25 & 37 & 30 & Fen & 1558 & 0.74 & 37 & 9 & 29 & 21 \\
\hline Tussock & 1273 & 0.66 & 52 & 33 & 43 & 33 & Tussock & 1273 & 0.68 & 45 & 24 & 38 & 26 \\
\hline Heath & 2347 & 0.65 & 43 & 15 & 35 & 28 & Heath & 2347 & 0.68 & 39 & -3 & 31 & 21 \\
\hline \multirow[t]{3}{*}{ Total } & 5178 & 0.71 & 46 & 23 & 38 & 35 & Total & 5178 & 0.69 & 40 & 7 & 32 & 30 \\
\hline & & \multicolumn{5}{|c|}{$H$} & & & \multicolumn{5}{|c|}{$H_{\mathrm{BR}}$} \\
\hline & $n$ & $R^{2}$ & RMSE & MBE & MAD & MAPD & & $n$ & $R^{2}$ & RMSE & $\mathrm{MBE}$ & MAD & MAPD \\
\hline Fen & 1558 & 0.66 & 28 & -6 & 22 & 23 & Fen & 1558 & 0.69 & 39 & -24 & 31 & 27 \\
\hline Tussock & 1273 & 0.65 & 33 & -12 & 26 & 24 & Tussock & 1273 & 0.67 & 39 & -22 & 29 & 26 \\
\hline Heath & 2347 & 0.71 & 33 & 4 & 26 & 26 & Heath & 2347 & 0.72 & 38 & -14 & 30 & 25 \\
\hline Total & 5178 & 0.67 & 32 & -3 & 25 & 25 & Total & 5178 & 0.69 & 39 & -19 & 31 & 30 \\
\hline
\end{tabular}

Table 6. Accuracy and error statistics from the comparison of modeled vs. observed unclosed and closed surface fluxes using $\alpha_{\mathrm{PTC}}$ of 1.26 . $n$ is the number of half-hour periods analyzed. RMSE, MAD and MBE are in $\mathrm{W} \mathrm{m}^{-2}$ and MAPD is in \%.

\begin{tabular}{|c|c|c|c|c|c|c|c|c|c|c|c|c|c|}
\hline & & \multicolumn{5}{|c|}{$R_{\mathrm{n}}$} & & & \multicolumn{5}{|c|}{ LE } \\
\hline & $n$ & $R^{2}$ & RMSE & MBE & MAD & MAPD & & $n$ & $R^{2}$ & RMSE & MBE & MAD & MAPD \\
\hline Fen & 1558 & 0.99 & 23 & 8 & 18 & 7 & Fen & 1558 & 0.66 & 58 & 45 & 52 & 45 \\
\hline Tussock & 1273 & 0.99 & 25 & 12 & 19 & 7 & Tussock & 1273 & 0.54 & 59 & 52 & 50 & 48 \\
\hline Heath & 2347 & 0.99 & 20 & 2 & 15 & 6 & Heath & 2347 & 0.52 & 57 & 39 & 47 & 42 \\
\hline \multirow[t]{3}{*}{ Total } & 5178 & 0.99 & 23 & 7 & 18 & 7 & Total & 5178 & 0.59 & 58 & 45 & 50 & 45 \\
\hline & & \multicolumn{5}{|c|}{$\mathrm{LE}_{\mathrm{BR}}$} & & & \multicolumn{5}{|c|}{$\mathrm{LE}_{\mathrm{RES}}$} \\
\hline & $n$ & $R^{2}$ & RMSE & MBE & MAD & MAPD & & $n$ & $R^{2}$ & RMSE & MBE & MAD & MAPD \\
\hline Fen & 1558 & 0.73 & 52 & 36 & 43 & 35 & Fen & 1558 & 0.76 & 41 & 20 & 34 & 24 \\
\hline Tussock & 1273 & 0.64 & 56 & 40 & 48 & 37 & Tussock & 1273 & 0.7 & 53 & 36 & 45 & 31 \\
\hline Heath & 2347 & 0.66 & 48 & 26 & 40 & 32 & Heath & 2347 & 0.71 & 40 & 9 & 32 & 22 \\
\hline \multirow[t]{3}{*}{ Total } & 5178 & 0.66 & 51 & 32 & 43 & 40 & Total & 5178 & 0.7 & 44 & 19 & 36 & 33 \\
\hline & & \multicolumn{5}{|c|}{$H$} & & & \multicolumn{5}{|c|}{$H_{\mathrm{BR}}$} \\
\hline & $n$ & $R^{2}$ & RMSE & MBE & MAD & MAPD & & $n$ & $R^{2}$ & RMSE & $\mathrm{MBE}$ & MAD & MAPD \\
\hline Fen & 1558 & 0.62 & 33 & -18 & 26 & 27 & Fen & 1558 & 0.64 & 46 & -34 & 38 & 33 \\
\hline Tussock & 1273 & 0.6 & 39 & -24 & 31 & 29 & Tussock & 1273 & 0.62 & 43 & -29 & 35 & 28 \\
\hline Heath & 2347 & 0.67 & 33 & -8 & 26 & 26 & Heath & 2347 & 0.65 & 43 & -25 & 35 & 28 \\
\hline Total & 5178 & 0.64 & 35 & -15 & 28 & 27 & Total & 5178 & 0.64 & 44 & -29 & 36 & 36 \\
\hline
\end{tabular}




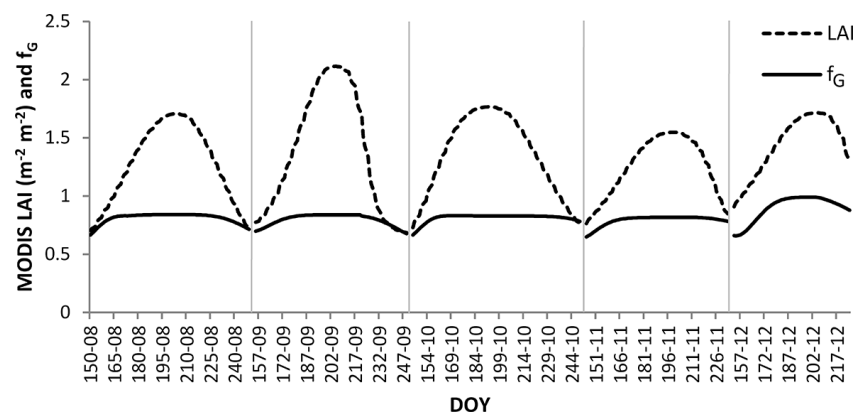

Figure 6. Mean MODIS LAI and fraction of green vegetation $\left(f_{\mathrm{g}}\right)$ temporal dynamics for all flux stations from 2008 to 2012.

may be reduced by using a land cover class-dependent value of $\alpha_{\text {PTC }}$.

Currently, there is limited research published on application of energy balance models to estimate energy fluxes for Arctic tundra. Mu et al. (2009) reported year-round errors from 20 to $40 \%$ in two Arctic tundra sites in Barrow (Alaska, USA) at daily periods based on a modified aerodynamic resistance-surface energy balance model where the required surface conductance is estimated from remotely sensed LAI based on the Cleugh et al. (2007) formulation. TSEB results, however, were evaluated with half-hourly data in summer conditions and, although they cannot be directly compared with results in this previous study, they show similar errors. As in the case of $R_{\mathrm{n}}, \mathrm{LE}$ and $H$ results are also in line with previous works for other cover types using in situ data as input to TSEB (Anderson et al., 2000, 2008; Li et al., 2005).

\subsection{Seasonal dynamics of surface energy fluxes and energy partitioning}

In general, monthly estimation of surface energy fluxes showed a good agreement with observations during the growing season. Because the model yielded similar results with both $\alpha_{\text {PTC }}$ parameterizations of 0.92 and 1.26 , this section only shows the seasonal dynamics with $\alpha_{\text {PTC }}$ of 0.92 . Because of the undermeasurement issues with eddy covariance data and greater uncertainty and error associated with LE measurements (Wolf et al., 2008), seasonal dynamics of turbulent fluxes were compared with residual LE. Estimated $R_{\mathrm{n}}$ yielded a low MAPD around $6 \%$, increasing up to $12 \%$ at the end of the growing season (Table 7 and Fig. 5). The proposed new method to estimate $G$ yielded better MAPD results from June to August, which coincides with the peak of the growing season in July. A similar pattern was found for LE and $H$, where the best MAPD results occurred also in the middle of the growing season (June and July). MAPD for LE, $H$ and $G$ tended to be higher in May and September, thus coinciding with earlier plant growth or the senesce periods, respectively. The MODIS LAI product, used to estimate the fractional vegetation cover (Eq. 3) to partition soil and canopy temperatures, performed as a good proxy to
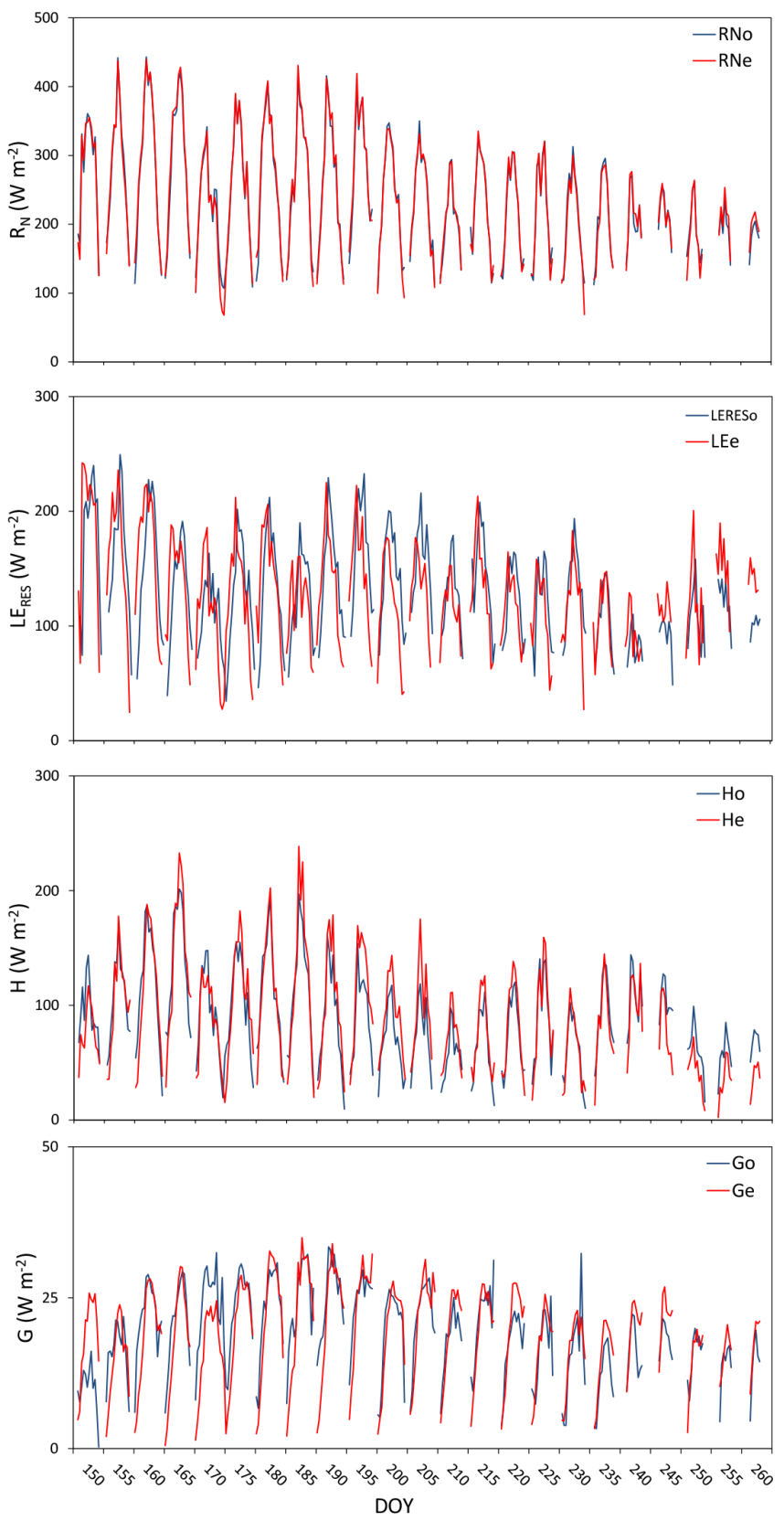

Figure 7. Comparison of hourly flux tower RN, LE, $H$ and $G$ observations (using LE from residual closure) (o) (from 06:00 to 21:00 LST) at the Heath flux tower with model estimates (e) using $\alpha_{\text {PTC }}$ of 0.92 . Each diurnal segment represents flux data averaged by hour over 5-day intervals from 2008 to 2012.

capture inter- and intra-annual vegetation dynamics (Fig. 6). Mean seasonal MODIS LAI from May to September for all flux stations was $1.2 \pm 0.5 \mathrm{~m}^{2} \mathrm{~m}^{-2}$. Previous studies close to the study area, in Toolik Lake and Imnavait Creek (Shaver and Chapin, 1991; Shippert et al., 1995; Williams et al., 2001; Williams et al., 2006), reported LAI field estimates ranging from 0.2 to $1.4 \mathrm{~m}^{2} \mathrm{~m}^{-2}$ for different tundra types 
Table 7. Mean monthly accuracy and error statistics from the comparison of modeled vs. observed surface fluxes (using LE from residual closure) using $\alpha_{\text {PTC }}$ of 0.92. $n$ is the number of half-hour periods analyzed. RMSE, MAD and MBE are in W m ${ }^{-2}$ and MAPD is in $\%$.

\begin{tabular}{|c|c|c|c|c|c|c|c|c|c|c|c|}
\hline & \multirow[b]{2}{*}{$n$} & \multicolumn{5}{|c|}{$R_{\mathrm{n}}$} & \multicolumn{5}{|c|}{ LE } \\
\hline & & $R^{2}$ & RMSE & MBE & MAD & MAPD & $R^{2}$ & RMSE & MBE & MAD & MAPD \\
\hline May & 227 & 0.99 & 24 & 7 & 19 & 7 & 0.78 & 46 & 28 & 38 & 23 \\
\hline June & 1727 & 0.99 & 22 & 6 & 17 & 6 & 0.73 & 40 & 11 & 32 & 20 \\
\hline July & 1647 & 0.99 & 21 & 5 & 17 & 6 & 0.72 & 39 & -7 & 31 & 20 \\
\hline August & 1264 & 0.99 & 23 & 6 & 19 & 8 & 0.64 & 37 & 7 & 30 & 24 \\
\hline \multirow[t]{3}{*}{ September } & 312 & 0.99 & 26 & 14 & 23 & 12 & 0.44 & 52 & 39 & 46 & 45 \\
\hline & & \multicolumn{5}{|c|}{$H$} & \multicolumn{5}{|c|}{$G$} \\
\hline & $n$ & $R^{2}$ & RMSE & $\mathrm{MBE}$ & MAD & MAPD & $R^{2}$ & RMSE & MBE & MAD & MAPD \\
\hline May & 227 & 0.69 & 36 & -22 & 29 & 27 & 0.12 & 10 & 1 & 8 & 48 \\
\hline June & 1727 & 0.71 & 32 & -6 & 25 & 20 & 0.45 & 7 & 0 & 6 & 26 \\
\hline July & 1647 & 0.72 & 32 & 10 & 25 & 29 & 0.49 & 6 & 1 & 5 & 23 \\
\hline August & 1264 & 0.62 & 37 & 7 & 30 & 24 & 0.40 & 7 & 3 & 6 & 34 \\
\hline September & 312 & 0.39 & 38 & -31 & 32 & 42 & 0.27 & 7 & 4 & 5 & 40 \\
\hline
\end{tabular}

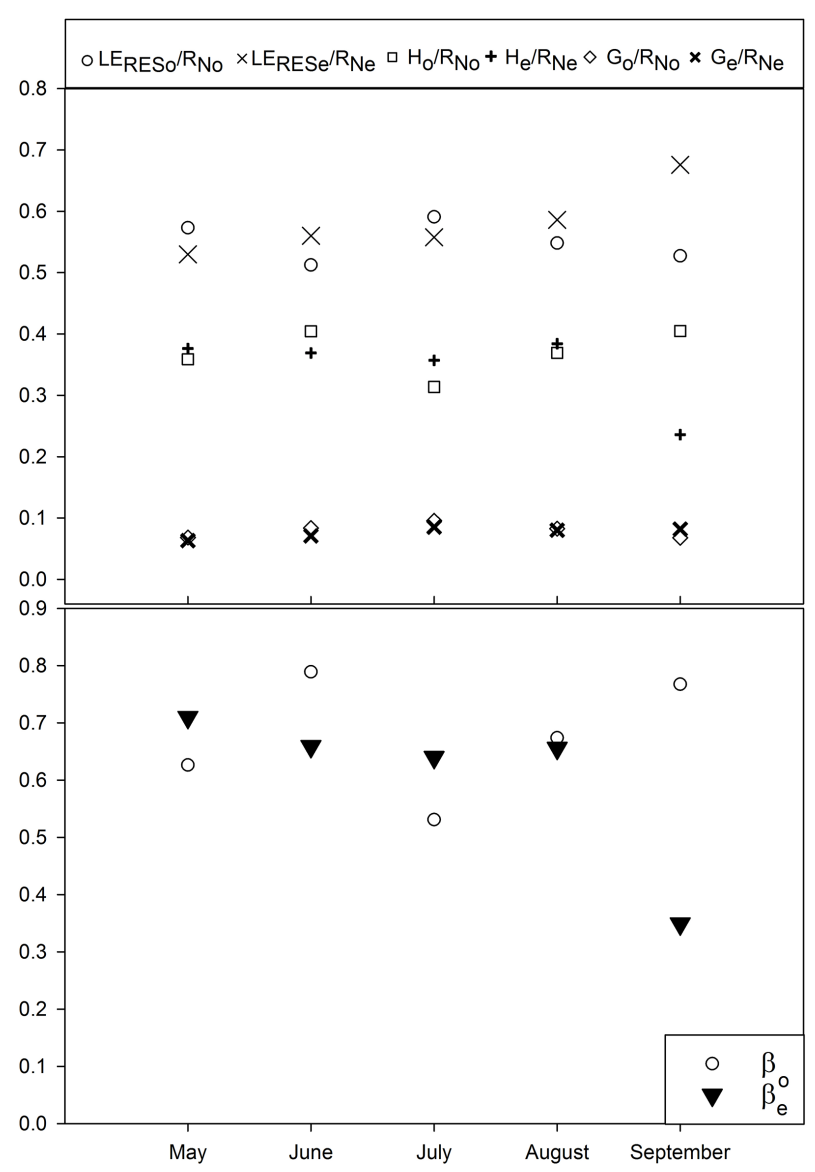

Figure 8. Monthly mean observed (o) and estimated (e) energy partitioning (LE / RN, $H / \mathrm{RN}$ and $G / \mathrm{RN}$ ) and Bowen ratio $(\beta)$ for all flux stations from 2008 to 2012 using $\alpha_{\text {PTC }}$ of 0.92 . around mid-July to mid-August, suggesting LAI overestimation from the MODIS product. Loranty et al. (2010) also reported LAI overestimation when using this product in similar tundra types, finding better agreement using a NDVI-LAI relationship (Shaver et al., 2007; Street et al., 2007), although the nonlinearity in the NDVI-LAI conversion is prone to averaging errors when scaled with remote sensing data (Stoy et al., 2009). Despite MODIS LAI overestimation, it performed well for the Arctic tundra, suggesting utility for regional applications, although NDVI-LAI methods might be considered for future applications.

$f_{\mathrm{g}}$ estimated through NDVI and EVI also captured interand intra-annual vegetation dynamics (Fig. 6), with a mean seasonal value from May to September for all flux stations of $0.82 \pm 0.7$. From May to August (from the beginning and almost to the end of the growing period), $f_{\mathrm{g}}$ showed a good agreement with LAI dynamics. However, while $f_{\mathrm{g}}$ showed a steady increase at the beginning of the growing season, it did not follow MODIS LAI dynamics in September. This caused the model to overestimate LE and underestimate $H$ during this time period, degrading agreement with observed data. The underperformance of the $f_{\mathrm{g}}$ methods near the end of the growing season might be related to the presence of a variable moss layer, which can exert strong controls on understory water and heat fluxes in Arctic tundra ecosystems (Blok et al., 2011) and may have masked the actual vegetation dynamics (Fig. 6). Further research is needed to confirm this hypothesis. The pattern of daily estimated surface energy fluxes also compared well to observed fluxes for all sky conditions. As an example, time series of modeled and measured surface energy fluxes are segmented in Fig. 7 for the Heath flux station, with each diurnal segment representing flux data averaged by hour over 5-day intervals from 2008 to 2012. Observed and estimated $R_{\mathrm{n}}$ exhibited an excellent agreement 
showing almost the same daily temporal pattern for the full growing season while LE, $H$ and $G$ yielded a good daily agreement being underestimated in May and September, especially in the case of LE.

In terms of observed (o) and estimated (e) mean season energy flux partitioning, $\mathrm{LE}_{\mathrm{o}} / R_{\mathrm{No}}, H_{\mathrm{O}} / R_{\mathrm{No}}$ and $G_{\mathrm{o}} / R_{\mathrm{No}}$ yielded mean values of $0.55,0.37$ and 0.08 , respectively, and $\mathrm{LE}_{\mathrm{e}} / \mathrm{RN}_{\mathrm{e}}, H_{\mathrm{e}} / R_{\mathrm{Ne}}$ and $G_{\mathrm{e}} / R_{\mathrm{Ne}}$ yielded mean values of $0.58,0.34$ and 0.08 , respectively (Fig. 8). Observed and estimated Bowen ratio $(\beta)$ yielded mean values of 0.60 and 0.67 , respectively. In all cases, observed and estimated results are in line with previous studies for Arctic tundra (Lynch et al., 1999; Eugster et al., 2000). It is worth noting that the difference between observed and estimated values of $L E / R_{\mathrm{n}}$ and $H / R_{\mathrm{n}}$ partitions was only around $3 \%$ and for $G / R_{\mathrm{n}}$ was almost negligible. From June to August, mean absolute difference values between observed and estimated values for LE $/ R_{\mathrm{n}}$ and $H / R_{\mathrm{n}}$ were around $4 \%$, increasing up to $15 \%$ in September due to model over- and underestimation, while the $G / R_{\mathrm{n}}$ difference was only less than $1 \%$.

These results suggest that the model is able to reproduce accurately temporal trends of energy partition in concert with tundra vegetation dynamics in the growing vegetation peak from June to August and could be used to monitor changes in surface energy fluxes concurrently with vegetation dynamics.

\section{Conclusions and future work}

Parameterizations for $R_{\mathrm{n}}, G$ and $\alpha_{\text {PTC }}$ used in the TSEB model were evaluated and refined for applications in different tundra types in Alaska over the full Arctic tundra growing season. Results showed that TSEB may adequately reproduce energy fluxes in Arctic tundra during the growing season, from leaf-out until senescence. The modified TSEB provided turbulent heat flux estimates with a mean RMSE value on the order of $50 \mathrm{~W} \mathrm{~m}^{-2}$ in comparison with unclosed eddy covariance measurements of $H$ and LE collected at three flux towers - commensurate with errors typically reported in other surface energy balance studies. Moreover, as in many other studies using eddy covariance flux data for evaluating model performance, imposing energy balance closure yielded better agreement between measured and modeled turbulent fluxes. The all sky $R_{\mathrm{n}}$ estimation scheme tested here yielded similar errors to those from other studies for only clear sky conditions. This demonstrates potential for regional-scale applications when reliable sources of solar radiation, air temperature and $T_{\mathrm{RAD}}$ are available. A refined model for soil heat flux $(G)$, based on the soil temperature- $G$ relationship, was evaluated from the green-up phase to senescence using data from multiple years, and yielded errors half the magnitude of the standard TSEB formulation based on the relationship between $R_{N_{\mathrm{S}}}$ and $G$. The TSEB $\alpha_{\mathrm{PTC}}$ parameterization for estimating canopy transpiration $\left(\mathrm{LE}_{\mathrm{c}}\right)$ was tested using the standard TSEB value of 1.26 and a value of 0.92 suggested in the literature for Arctic tundra, and both parameterizations yield similar flux errors suggesting tundraspecific values of $\alpha_{\text {PTC }}$ are not needed.

In the absence of in situ measurements of LAI within the vicinity of the tower sites, the MODIS LAI product provided reasonable inputs for localized model testing. The model was able to reproduce accurately temporal trends of energy partitioning in concert with tundra vegetation dynamics in the peak growing season. Moreover, it also has potential to monitor changes in surface energy fluxes in Arctic tundra due to changes in vegetation composition (e.g., shrub encroachment). This is particularly crucial in the Arctic where there is a sparse network of meteorological and flux observations. Further research is needed regarding the specific role of the moss layer in modifying remote sensing estimates of green vegetation cover fraction and soil heat conduction within tundra ecosystems.

Future work will incorporate the TSEB model refinements identified here for Arctic tundra into regional and global applications of the ALEXI surface energy balance modeling system. Model performance within a fully satellite-based remote sensing framework will be compared to the local evaluations reported here at these tundra flux sites. In addition, the diagnostic assessments of ET and surface energy fluxes will be compared with regional output from process-based prognostic land surface models to better understand the strengths and weaknesses of both types of modeling systems.

Data availability. The MODIS data were downloaded from https:// reverb.echo.nasa.gov/reverb/. Fen, tussock and heath flux tower data were obtained from the Arctic Observatory Network (AON) (http: //aon.iab.uaf.edu/imnavait).

Competing interests. The authors declare that they have no conflict of interest.

Acknowledgements. We would like to thank the anonymous reviewers for their insightful comments and suggestions, which we believe have significantly improved the quality and clarity of this paper. This research was supported by the Alaska NASA EPSCoR program awards NNX10NO2A and NNX13AB28A. Authors would also like to thank Colin Edgar from the Institute of Arctic Biology, UAF, for his help in data processing of the eddy covariance and meteorological data. Datasets from the Imnavait sites were provided by the Institute of Arctic Biology, UAF, based upon work supported by the National Science Foundation under grant no. 1107892 . USDA is an equal opportunity employer and provider.

Edited by: M. Hipsey

Reviewed by: two anonymous referees 


\section{References}

ACIA: Impacts of a Warming Arctic, Cambridge University Press, Cambridge, 140 pp., 2004.

Agam, N., Kustas, W. P., Anderson, M. C., Norman, J. M., Colaizzi, P. D., Howell, T. A., Prueger, J. H., Meyers, T. P., and Wilson, T. B.: Application of the Priestley-Taylor Approach in a TwoSource Surface Energy Balance Model, J. Hydrometeorol., 11, 185-198, doi:10.1175/2009jhm1124.1, 2010.

AMAP: Arctic Climate Issues 2011: Changes in Arctic Snow, Water, Ice and Permafrost. SWIPA 2011, Overview Report, Oslo, Norway, 96 pp., 2012.

Anderson, M. C., Norman, J. M., Meyers, T. P., and Diak, G. R.: An analytical model for estimating canopy transpiration and carbon assimilation fluxes based on canopy light-use efficiency, Agr. Forest Meteorol., 101, 265-289, doi:10.1016/S01681923(99)00170-7, 2000.

Anderson, M. C., Norman, J. M., Mecikalski, J. R., Torn, R. D., Kustas, W. P., and Basara, J. B.: A multiscale remote sensing model for disaggregating regional fluxes to micrometeorological scales, J. Hydrometeorol., 5, 343-363, 2004.

Anderson, M. C., Norman, J. M., Kustas, W. P., Li, F. Q., Prueger, J. H., and Mecikalski, J. R.: Effects of vegetation clumping on two-source model estimates of surface energy fluxes from an agricultural landscape during SMACEX, J. Hydrometeorol., 6, 892-909, doi:10.1175/Jhm465.1, 2005.

Anderson, M. C., Kustas, W. P., and Norman, J. M.: Upscaling Flux Observations from Local to Continental Scales Using Thermal Remote Sensing, Agron. J., 99, 240-254, doi:10.2134/agronj2005.0096S, 2007.

Anderson, M. C., Norman, J., Kustas, W., Houborg, R., Starks, P., and Agam, N.: A thermal-based remote sensing technique for routine mapping of land-surface carbon, water and energy fluxes from field to regional scales, Remote Sens. Environ., 112, 42274241, doi:10.1016/j.rse.2008.07.009, 2008.

Anderson, M. C., Kustas, W. P., Norman, J. M., Hain, C. R., Mecikalski, J. R., Schultz, L., González-Dugo, M. P., Cammalleri, C., d'Urso, G., Pimstein, A., and Gao, F.: Mapping daily evapotranspiration at field to continental scales using geostationary and polar orbiting satellite imagery, Hydrol. Earth Syst. Sci., 15, 223-239, doi:10.5194/hess-15-223-2011, 2011.

Anderson, M. C., Kustas, W. P., Alfieri, J. G., Gao, F., Hain, C., Prueger, J. H., Evett, S., Colaizzi, P., Howell, T., and Chávez, J. L.: Mapping daily evapotranspiration at Landsat spatial scales during the BEAREX'08 field campaign, Adv. Water Resour., 50, 162-177, doi:10.1016/j.advwatres.2012.06.005, 2012.

Beringer, J., Chapin, F. S., Thompson, C. C., and McGuire, A. D.: Surface energy exchanges along a tundra-forest transition and feedbacks to climate, Agr. Forest Meteorol., 131, 143-161, doi:10.1016/j.agrformet.2005.05.006, 2005.

Beck, P. S. A., Atzberger, C., Hogda, K. A., Johansen, B., and Skidmore, A. K.: Improved monitoring of vegetation dynamics at very high latitudes: A new method using MODIS NDVI, Remote Sens. Environ., 100, 321-334, doi:10.1016/j.rse.2005.10.021, 2006.

Bhatt, U. S., Walker, D. A., Raynolds, M. K., Comiso, J. C., Epstein, H. E., Jia, G. S., Gens, R., Pinzon, J. E., Tucker, C. J., Tweedie, C. E., and Webber, P. J.: Circumpolar Arctic Tundra Vegetation Change Is Linked to Sea Ice Decline, Earth Interact., 14, 1-20, doi:10.1175/2010ei315.1, 2010.
Blok, D., Heijmans, M. M. P. D., Schaepman-Strub, G., van Ruijven, J., Parmentier, F. J. W., Maximov, T. C., and Berendse, F.: The Cooling Capacity of Mosses: Controls on Water and Energy Fluxes in a Siberian Tundra Site, Ecosystems, 14, 1055-1065, doi:10.1007/s10021-011-9463-5, 2011.

Boike, J., Hagedorn, B., and Roth, K.: Heat and Water Transfer Processes in Permafrost Affected Soils: A Review of Field and Modeling Based Studies for the Arctic and Antarctic, Plenary Paper, Proceedings of the 9th International Conference on Permafrost, June 29-July 3, 2008, University of Alaska, Fairbanks, USA, 2008a.

Boike, J., Wille, C., and Abnizova, A.: Climatology and summer energy and water balance of polygonal tundra in the Lena River Delta, Siberia, J. Geophys. Res.-Biogeo., 113, G03025, doi:10.1029/2007jg000540, 2008b.

Brutsaert, W.: On a derivable formula for long-wave radiation from clear skies, Water Resour. Res., 11, 742-744, doi:10.1029/WR011i005p00742, 1975.

Cammalleri, C., Anderson, M. C., Ciraolo, G., D’Urso, G., Kustas, W. P., La Loggia, G., and Minacapilli, M.: The impact of incanopy wind profile formulations on heat flux estimation in an open orchard using the remote sensing-based two-source model, Hydrol. Earth Syst. Sci., 14, 2643-2659, doi:10.5194/hess-142643-2010, 2010.

Cammalleri, C., Anderson, M. C., Ciraolo, G., D’Urso, G., Kustas, W. P., La Loggia, G., and Minacapilli, M.: Applications of a remote sensing-based two-source energy balance algorithm for mapping surface fluxes without in situ air temperature observations, Remote Sens. Environ., 124, 502-515, doi:10.1016/j.rse.2012.06.009, 2012.

Choi, M., Kustas, W. P., Anderson, M. C., Allen, R. G., Li, F., and Kjaersgaard, J. H.: An intercomparison of three remote sensing-based surface energy balance algorithms over a corn and soybean production region (Iowa, U.S.) during SMACEX, Agr. Forest Meteorol., 149, 2082-2097, doi:10.1016/j.agrformet.2009.07.002, 2009.

Cleugh, H. A., Leuning, R., Mu, Q. Z., and Running, S. W.: Regional evaporation estimates from flux tower and MODIS satellite data, Remote Sens. Environ., 106, 285-304, doi:10.1016/j.rse.2006.07.007, 2007.

Courault, D., Seguin, B., and Olioso, A.: Review on estimation of evapotranspiration from remote sensing data: From empirical to numerical modeling approaches, Irrigation and Drainage Systems, 19, 223-249, 2005.

Crawford, T. M. and Duchon, C. E.: An improved parameterization for estimating effective atmospheric emissivity for use in calculating daytime downwelling longwave radiation, J. Appl. Meteorol., 38, 474-480, doi:10.1175/15200450(1999)038<0474:AIPFEE>2.0.CO;2, 1999.

Cristóbal, J. and Anderson, M. C.: Validation of a Meteosat Second Generation solar radiation dataset over the northeastern Iberian Peninsula, Hydrol. Earth Syst. Sci., 17, 163-175, doi:10.5194/hess-17-163-2013, 2013.

Cristóbal, J., Ninyerola, M., and Pons, X.: Modeling air temperature through a combination of remote sensing and GIS data, J. Geophys. Res., 113, D13106, doi:10.1029/2007jd009318, 2008.

Daughtry, C. S. T., Kustas, W. P., Moran, M. S., Pinter, P. J., Jackson, R. D., Brown, P. W., Nichols, W. D., and Gay, L. W.: Spectral Estimates of Net-Radiation and Soil Heat-Flux, Remote 
Sens. Environ., 32, 111-124, doi:10.1016/0034-4257(90)90012B, 1990.

Deardorff, J. W.: Efficient prediction of ground surface temperature and moisture, with inclusion of a layer of vegetation, J. Geophys. Res., 83, 1889, doi:10.1029/JC083iC04p01889, 1978.

Domingo, F., Villagarcia, L., Brenner, A. J., and Puigdefabregas, J.: Measuring and modelling the radiation balance of a heterogeneous shrubland, Plant Cell Environ., 23, 27-38, doi:10.1046/j.1365-3040.2000.00532.x, 2000.

Duursma, R. A. and Medlyn, B. E.: MAESPA: a model to study interactions between water limitation, environmental drivers and vegetation function at tree and stand levels, with an example application to $\left[\mathrm{CO}_{2}\right] \times$ drought interactions, Geosci. Model Dev., 5, 919-940, doi:10.5194/gmd-5-919-2012, 2012.

Eaton, A. K., Rouse, W. R., Lafleur, P. M., Marsh, P., and Blanken, P. D.: Surface energy balance of the western and central Canadian subarctic: Variations in the energy balance among five major terrain types, J. Climate, 14, 3692-3703, doi:10.1175/15200442(2001)014<3692:SEBOTW>2.0.CO;2, 2001.

EddyPro $^{\circledR}$ : (Version 5) [Computer software], Lincoln, NE. LICOR, Inc, Infrastructure for Measurements of the European Carbon Cycle consortium, 2014.

Ek, M. B., Mitchell, K. E., Lin, Y., Rogers, E., Grunmann, P., Koren, V., Gayno, G., and Tarpley, J. D.: Implementation of Noah land surface model advances in the National Centers for Environmental Prediction operational mesoscale Eta model, J. Geophys. Res.-Atmos., 108, 8851, doi:10.1029/2002jd003296, 2003.

Ekici, A., Chadburn, S., Chaudhary, N., Hajdu, L. H., Marmy, A., Peng, S., Boike, J., Burke, E., Friend, A. D., Hauck, C., Krinner, G., Langer, M., Miller, P. A., and Beer, C.: Site-level model intercomparison of high latitude and high altitude soil thermal dynamics in tundra and barren landscapes, The Cryosphere, 9, 1343-1361, doi:10.5194/tc-9-1343-2015, 2015.

Elmendorf, S. C., Henry, G. H. R., Hollister, R. D., Bjork, R. G., Boulanger-Lapointe, N., Cooper, E. J., Cornelissen, J. H. C., Day, T. A., Dorrepaal, E., Elumeeva, T. G., Gill, M., Gould, W. A., Harte, J., Hik, D. S., Hofgaard, A., Johnson, D. R., Johnstone, J. F., Jonsdottir, I. S., Jorgenson, J. C., Klanderud, K., Klein, J. A., Koh, S., Kudo, G., Lara, M., Levesque, E., Magnusson, B., May, J. L., Mercado-Diaz, J. A., Michelsen, A., Molau, U., Myers-Smith, I. H., Oberbauer, S. F., Onipchenko, V. G., Rixen, C., Schmidt, N. M., Shaver, G. R., Spasojevic, M. J., Porhallsdottir, P. E., Tolvanen, A., Troxler, T., Tweedie, C. E., Villareal, S., Wahren, C. H., Walker, X., Webber, P. J., Welker, J. M., and Wipf, S.: Plot-scale evidence of tundra vegetation change and links to recent summer warming, Nature Climate Change, 2, 453-457, doi:10.1038/Nclimate1465, 2012.

Engstrom, R. N., Hope, A. S., Stow, D. A., Vourlitis, G. L., and Oechel, W. C.: Priestley-Taylor Alpha Coefficient: Variability and Relationship to Ndvi in Arctic Tundra Landscapes, J. Am. Water Resour. As., 38, 1647-1659, doi:10.1111/j.17521688.2002.tb04371.x, 2002.

Eugster, W., Rouse, W. R., Pielke, R. A., McFadden, J. P., Baldocchi, D. D., Kittel, T. G. F., Chapin, F. S., Liston, G. E., Vidale, P. L., Vaganov, E., and Chambers, S.: Land-atmosphere energy exchange in Arctic tundra and boreal forest: available data and feedbacks to climate, Glob. Change Biol., 6, 84-115, doi:10.1046/j.1365-2486.2000.06015.x, 2000.
Eugster, W., McFadden, J. P., and Chapin, F. S.: Differences in Surface Roughness, Energy, and $\mathrm{CO}_{2}$ Fluxes in Two Moist Tundra Vegetation Types, Kuparuk Watershed, Alaska, USA, 2005.

Euskirchen, E. S., Bret-Harte, M. S., Scott, G. J., Edgar, C., and Shaver, G. R.: Seasonal patterns of carbon dioxide and water fluxes in three representative tundra ecosystems in northern Alaska, Ecosphere, 3, 1-19, doi:10.1890/es11-00202.1, 2012.

Falge, E., Reth, S., Bruggemann, N., Butterbach-Bahl, K., Goldberg, V., Oltchev, A., Schaaf, S., Spindler, G., Stiller, B., Queck, R., Kostner, B., and Bernhofer, C.: Comparison of surface energy exchange models with eddy flux data in forest and grassland ecosystems of Germany, Ecol. Model., 188, 174-216, doi:10.1016/j.ecolmodel.2005.01.057, 2005.

Fisher, J. B., Tu, K. P., and Baldocchi, D. D.: Global estimates of the land-atmosphere water flux based on monthly AVHRR and ISLSCP-II data, validated at 16 FLUXNET sites, Remote Sens. Environ., 112, 901-919, doi:10.1016/j.rse.2007.06.025, 2008.

Foken, T.: The energy balance closure problem: an overview, Ecol. Appl., 18, 1351-1367, doi:10.1890/06-0922.1, 2008.

Foken, T., Aubinet, M., Finnigan, J. J., Leclerc, M. Y., Mauder, M., and Paw U, K. T.: Results of a Panel Discussion About the Energy Balance Closure Correction for Trace Gases, B. Am. Meteorol. Soc., 92, Es13-Es18, doi:10.1175/2011BAMS3130.1, 2011.

Frank, J. M., Massman, W. J., and Ewers, B. E.: Underestimates of sensible heat flux due to vertical velocity measurement errors in non-orthogonal sonic anemometers, Agr. Forest Meteorol., 171, 72-81, doi:10.1016/j.agrformet.2012.11.005, 2013.

Gao, F., Morisette, J. T., Wolfe, R. E., Ederer, G., Pedelty, J., Masuoka, E., Myneni, R., Tan, B., and Nightingale, J.: An algorithm to produce temporally and spatially continuous MODIS-LAI time series, IEEE Geosci. Remote S., 5, 60-64, doi:10.1109/Lgrs.2007.907971, 2008.

Guzinski, R., Anderson, M. C., Kustas, W. P., Nieto, H., and Sandholt, I.: Using a thermal-based two source energy balance model with time-differencing to estimate surface energy fluxes with day-night MODIS observations, Hydrol. Earth Syst. Sci., 17, 2809-2825, doi:10.5194/hess-17-2809-2013, 2013.

Hain, C. R., Crow, W. T., Anderson, M. C., and Yilmaz, M. T.: Diagnosing Neglected Soil Moisture Source-Sink Processes via a Thermal Infrared-Based Two-Source Energy Balance Model, J. Hydrometeorol., 16, 1070-1086, doi:10.1175/Jhm-D-14-0017.1, 2015.

Haverd, V., Raupach, M. R., Briggs, P. R., Canadell, J. G., Isaac, P., Pickett-Heaps, C., Roxburgh, S. H., van Gorsel, E., Viscarra Rossel, R. A., and Wang, Z.: Multiple observation types reduce uncertainty in Australia's terrestrial carbon and water cycles, Biogeosciences, 10, 2011-2040, doi:10.5194/bg-10-2011-2013, 2013.

Hinzman, L. D., Goering, D. J., and Kane, D. L.: A distributed thermal model for calculating soil temperature profiles and depth of thaw in permafrost regions, J. Geophys. Res.-Atmos., 103, 28975-28991, doi:10.1029/98jd01731, 1998.

IPCC: Climate Change 2014, Synthesis Report. Contribution of Working Groups I, II and III to the Fifth Assessment Report of the Intergovernmental Panel on Climate Change, edited by: Pachauri, R. K. and Meyer, L. A., IPCC, Geneva, Switzerland, 2014.

Jacobsen, A. and Hansen, B. U.: Estimation of the soil heat flux net radiation ratio based on spectral vegetation indexes in 
high-latitude Arctic areas, Int. J. Remote Sens., 20, 445-461, doi:10.1080/014311699213532, 1999.

Jia, G. J., Epstein, H. E., and Walker, D. A.: Greening of arctic Alaska, 1981-2001, Geophys. Res. Lett., 30, 2067, doi:10.1029/2003g1018268, 2003.

Jiang, Y. Y., Rocha, A. V., O’Donnell, J. A., Drysdale, J. A., Rastetter, E. B., Shaver, G. R., and Zhuang, Q. L.: Contrasting soil thermal responses to fire in Alaskan tundra and boreal forest, J. Geophys. Res.-Earth, 120, 363-378, doi:10.1002/2014JF003180, 2015.

Jin, X., Barber, D., and Papakyriakou, T.: A new clear-sky downward longwave radiative flux parameterization for Arctic areas based on rawinsonde data, J. Geophys. Res.-Atmos., 111, D24104, doi:10.1029/2005jd007039, 2006.

Jönsson, P. and Eklundh, L.: TIMESAT-a program for analyzing time-series of satellite sensor data, Comput. Geosci.-UK, 30, 833-845, doi:10.1016/j.cageo.2004.05.006, 2004.

Jung, M., Reichstein, M., Ciais, P., Seneviratne, S. I., Sheffield, J., Goulden, M. L., Bonan, G., Cescatti, A., Chen, J., de Jeu, R., Dolman, A. J., Eugster, W., Gerten, D., Gianelle, D., Gobron, N., Heinke, J., Kimball, J., Law, B. E., Montagnani, L., Mu, Q., Mueller, B., Oleson, K., Papale, D., Richardson, A. D., Roupsard, O., Running, S., Tomelleri, E., Viovy, N., Weber, U., Williams, C., Wood, E., Zaehle, S., and Zhang, K.: Recent decline in the global land evapotranspiration trend due to limited moisture supply, Nature, 467, 951-954, doi:10.1038/nature09396, 2010.

Kade, A., Bret-Harte, M. S., Euskirchen, E. S., Edgar, C., and Fulweber, R. A.: Upscaling of $\mathrm{CO}_{2}$ fluxes from heterogeneous tundra plant communities in Arctic Alaska, J. Geophys. Res., 117, G04007, doi:10.1029/2012jg002065, 2012.

Kalma, J. D., McVicar, T. R., and McCabe, M. F.: Estimating Land Surface Evaporation: A Review of Methods Using Remotely Sensed Surface Temperature Data, Surv. Geophys., 29, 421-469, doi:10.1007/s10712-008-9037-z, 2008.

Kane, D. L., Gieck, R. E., and Hinzman, L. D.: Evapotranspiration from a Small Alaskan Arctic Watershed, Nord. Hydrol., 21, 253272, 1990.

Kane, D. L., Hinzman, L. D., McNamara, J. P., Zhang, Z., and Benson, C. S.: An overview of a nested watershed study in Arctic Alaska, Nord. Hydrol., 31, 245-266, 2000.

Kane, D. L., Gieck, R. E., Kitover, D. C., Hinzman, L. D., Mcnamara, J. P., and Yang, D.: Hydrologic Cycle on the North Slope of Alaska, Northern Research Basins Water Balance, Victoria, Canada, 2004, 224-236, 2004.

Kochendorfer, J., Meyers, T. P., Frank, J., Massman, W. J., and Heuer, M. W.: How Well Can We Measure the Vertical Wind Speed? Implications for Fluxes of Energy and Mass, Bound.Lay. Meteorol., 145, 383-398, doi:10.1007/s10546-012-9738-1, 2012.

Kochendorfer, J., Meyers, T. P., Frank, J. M., Massman, W. J., and Heuer, M. W.: Reply to the Comment by Mauder on "How Well Can We Measure the Vertical Wind Speed? Implications for Fluxes of Energy and Mass", Bound.-Lay. Meteorol., 147, 337345, doi:10.1007/s10546-012-9792-8, 2012.

Kodama, Y., Sato, N., Yabuki, H., Ishii, Y., Nomura, M., and Ohata, T.: Wind direction dependency of water and energy fluxes and synoptic conditions over a tundra near Tiksi, Siberia, Hydrol. Process., 21, 2028-2037, doi:10.1002/hyp.6712, 2007.
Kustas, W. P. and Daughtry, C. S. T.: Estimation of the Soil HeatFlux Net-Radiation Ratio from Spectral Data, Agr. Forest Meteorol., 49, 205-223, doi:10.1016/0168-1923(90)90033-3, 1990.

Kustas, W. P. and Norman, J. M.: Evaluation of soil and vegetation heat flux predictions using a simple two-source model with radiometric temperatures for partial canopy cover, Agr. Forest Meteorol., 94, 13-29, doi:10.1016/S0168-1923(99)00005-2, 1999.

Kustas, W. P. and Norman, J. M.: A two-source energy balance approach using directional radiometric temperature observations for sparse canopy covered surfaces, Agron. J., 92, 847-854, 2000.

Kustas, W. P., Zhan, X., and Schmugge, T. J.: Combining optical and microwave remote sensing for mapping energy fluxes in a semiarid watershed, Remote Sens. Environ., 64, 116-131, doi:10.1016/S0034-4257(97)00176-4, 1998.

Langer, M., Westermann, S., Muster, S., Piel, K., and Boike, J.: The surface energy balance of a polygonal tundra site in northern Siberia - Part 1: Spring to fall, The Cryosphere, 5, 151-171, doi:10.5194/tc-5-151-2011, 2011.

Li, F., Kustas, W. P., Anderson, M. C., Prueger, J. H., and Scott, R. L.: Effect of remote sensing spatial resolution on interpreting tower-based flux observations, Remote Sens. Environ., 112, 337349, doi:10.1016/j.rse.2006.11.032, 2008.

Li, F. Q., Kustas, W. P., Prueger, J. H., Neale, C. M. U., and Jackson, T. J.: Utility of remote sensing-based two-source energy balance model under low- and high-vegetation cover conditions, J. Hydrometeorol., 6, 878-891, doi:10.1175/Jhm464.1, 2005.

LI-COR Inc.: LI-7500 $\mathrm{CO}_{2} / \mathrm{H}_{2} \mathrm{O}$ analyzer instruction manual, LICOR, Lincoln, Nebraska, USA, 2004.

Loranty, M. M., Goetz, S. J., Rastetter, E. B., Rocha, A. V., Shaver, G. R., Humphreys, E. R., and Lafleur, P. M.: Scaling an Instantaneous Model of Tundra NEE to the Arctic Landscape, Ecosystems, 14, 76-93, doi:10.1007/s10021-010-9396-4, 2010.

Lund, M., Hansen, B. U., Pedersen, S. H., Stiegler, C., and Tamstorf, M. P.: Characteristics of summer-time energy exchange in a high Arctic tundra heath 2000-2010, Tellus B, 66, 1-14, doi:10.3402/Tellusb.V66.21631, 2014.

Lynch, A. H., Chapin, F. S., Hinzman, L. D., Wu, W., Lilly, E., Vourlitis, G., and Kim, E.: Surface energy balance on the arctic tundra: Measurements and models, J. Climate, 12, 2585-2606, doi:10.1175/1520-0442(1999)012<2585:SEBOTA>2.0.CO;2, 1999.

Massman, W. J.: A simple method for estimating frequency response corrections for eddy covariance systems, Agr. Forest Meteorol., 104, 185-198, doi:10.1016/S0168-1923(00)00164-7, 2000.

Mendez, J., Hinzman, L. D., and Kane, D. L.: Evapotranspiration from a wetland complex on the Arctic coastal plain of Alaska, Nord. Hydrol., 29, 303-330, 1998.

Mu, Q. Z., Jones, L. A., Kimball, J. S., McDonald, K. C., and Running, S. W.: Satellite assessment of land surface evapotranspiration for the pan-Arctic domain, Water Resour. Res., 45, W09420, doi:10.1029/2008wr007189, 2009.

Myers-Smith, I. H., Forbes, B. C., Wilmking, M., Hallinger, M., Lantz, T., Blok, D., Tape, K. D., Macias-Fauria, M., SassKlaassen, U., Levesque, E., Boudreau, S., Ropars, P., Hermanutz, L., Trant, A., Collier, L. S., Weijers, S., Rozema, J., Rayback, S. A., Schmidt, N. M., Schaepman-Strub, G., Wipf, S., Rixen, C., Menard, C. B., Venn, S., Goetz, S., Andreu-Hayles, L., Elmen- 
dorf, S., Ravolainen, V., Welker, J., Grogan, P., Epstein, H. E., and Hik, D. S.: Shrub expansion in tundra ecosystems: dynamics, impacts and research priorities, Environ. Res. Lett., 6, 1-15, doi:10.1088/1748-9326/6/4/045509, 2011.

Norman, J. M., Kustas, W. P., and Humes, K. S.: Source Approach for Estimating Soil and Vegetation Energy Fluxes in Observations of Directional Radiometric Surface-Temperature, Agr. Forest Meteorol., 77, 263-293, doi:10.1016/0168-1923(95)02265Y, 1995.

Norman, J. M., Kustas, W. P., Prueger, J. H., and Diak, G. R.: Surface flux estimation using radiometric temperature: A dualtemperature-difference method to minimize measurement errors, Water Resour. Res., 36, 2263, doi:10.1029/2000wr900033, 2000.

Overduin, P. P. and Kane, D. L.: Frost boils and soil ice content: Field observations, Permafrost. Periglac., 17, 291-307, doi:10.1002/Ppp.567, 2006.

Pons, X. and Ninyerola, M.: Mapping a topographic global solar radiation model implemented in a GIS and refined with ground data, Int. J. Climatol., 28, 1821-1834, doi:10.1002/Joc.1676, 2008.

Priestley, C. H. B. and Taylor, R. J.: On the assessment of surface heat flux and evaporation using large-scale parameters, Mon. Weather Rev., 100, 81-92, 1972.

Rannik, Ü.: A comment on the paper by W.J. Massman "A simple method for estimating frequency response corrections for eddy covariance systems", Agr. Forest Meteorol., 107, 241-245, doi:10.1016/S0168-1923(00)00236-7, 2001.

Rawlins, M. A., Steele, M., Holland, M. M., Adam, J. C., Cherry, J. E., Francis, J. A., Groisman, P. Y., Hinzman, L. D., Huntington, T. G., Kane, D. L., Kimball, J. S., Kwok, R., Lammers, R. B., Lee, C. M., Lettenmaier, D. P., McDonald, K. C., Podest, E., Pundsack, J. W., Rudels, B., Serreze, M. C., Shiklomanov, A., Skagseth, O., Troy, T. J., Vorosmarty, C. J., Wensnahan, M., Wood, E. F., Woodgate, R., Yang, D. Q., Zhang, K., and Zhang, T. J.: Analysis of the Arctic System for Freshwater Cycle Intensification: Observations and Expectations, J. Climate, 23, 57155737, doi:10.1175/2010jcli3421.1, 2010.

Rocha, A. V. and Shaver, G. R.: Burn severity influences postfire $\mathrm{CO}_{2}$ exchange in arctic tundra, Ecol. Appl., 21, 477-489, doi:10.1890/10-0255.1, 2011.

Romanovsky, V. E., Osterkamp, T. E., and Duxbury, N. S.: An evaluation of three numerical models used in simulations of the active layer and permafrost temperature regimes, Cold Reg. Sci. Technol., 26, 195-203, doi:10.1016/S0165-232x(97)00016-5, 1997.

Rouse, W. R.: Microclimate of Arctic Tree Line .2. Soil Microclimate of Tundra and Forest, Water Resour. Res., 20, 67-73, doi:10.1029/Wr020i001p00067, 1984.

Sánchez, J. M., Caselles, V., Niclòs, R., Coll, C., and Kustas, W. P.: Estimating energy balance fluxes above a boreal forest from radiometric temperature observations, Agr. Forest Meteorol., 149, 1037-1049, doi:10.1016/j.agrformet.2008.12.009, 2009.

Santanello, J. A. and Friedl, M. A.: Diurnal covariation in soil heat flux and net radiation, J. Appl. Meteorol., 42, 851-862, 2003.

Serreze, M. C. and Barry, R. G.: Processes and impacts of Arctic amplification: A research synthesis, Global Planet. Change, 77, 85-96, doi:10.1016/j.gloplacha.2011.03.004, 2011.

Shaver, G. R. and Chapin, F. S.: Production - Biomass Relationships and Element Cycling in Contrasting Arctic Vegetation Types, Ecol. Monogr., 61, 1-31, doi:10.2307/1942997, 1991.
Shaver, G. R., Street, L. E., Rastetter, E. B., Van Wijk, M. T., and Williams, M.: Functional convergence in regulation of net $\mathrm{CO}_{2}$ flux in heterogeneous tundra landscapes in Alaska and Sweden, J. Ecol., 95, 802-817, doi:10.1111/j.1365-2745.2007.01259.x, 2007.

Shippert, M. M., Walker, D. A., Auerbach, N. A., and Lewis, B. R.: Biomass and leaf-area index maps derived from SPOT images for Toolik Lake and Imnavait Creek areas, Alaska, Polar Rec., 31, 147-154, 1995.

Shutov, V., Gieck, R. E., Hinzman, L. D., and Kane, D. L.: Evaporation from land surface in high latitude areas: a review of methods and study results, Nordic Hydrol., 37, 393-411, doi:10.2166/Nh.2006.022, 2006.

Smith, B., Prentice, I. C., and Sykes, M. T.: Representation of vegetation dynamics in the modelling of terrestrial ecosystems: comparing two contrasting approaches within European climate space, Global Ecol. Biogeogr., 10, 621-637, doi:10.1046/j.1466822X.2001.t01-1-00256.x, 2001.

Soegaard, H., Hasholt, B., Friborg, T., and Nordstroem, C.: Surface energy- and water balance in a high-arctic environment in NE Greenland, Theor. Appl. Climatol., 70, 35-51, doi:10.1007/s007040170004, 2001.

Stoy, P. C., Mauder, M., Foken, T., Marcolla, B., Boegh, E., Ibrom, A., Arain, M. A., Arneth, A., Aurela, M., Bernhofer, C., Cescatti, A., Dellwik, E., Duce, P., Gianelle, D., van Gorsel, E., Kiely, G., Knohl, A., Margolis, H., McCaughey, H., Merbold, L., Montagnani, L., Papale, D., Reichstein, M., Saunders, M., Serrano-Ortiz, P., Sottocornola, M., Spano, D., Vaccari, F., and Varlagin, A.: A data-driven analysis of energy balance closure across FLUXNET research sites: The role of landscape scale heterogeneity, Agr. Forest Meteorol., 171, 137-152, doi:10.1016/j.agrformet.2012.11.004, 2013.

Stoy, P. C., Williams, M., Spadavecchia, L., Bell, R. A., PrietoBlanco, A., Evans, J. G., and van Wijk, M. T.: Using Information Theory to Determine Optimum Pixel Size and Shape for Ecological Studies: Aggregating Land Surface Characteristics in Arctic Ecosystems, Ecosystems, 12, 574-589, doi:10.1007/s10021009-9243-7, 2009.

Street, L. E., Shaver, G. R., Williams, M., and Van Wijk, M. T.: What is the relationship between changes in canopy leaf area and changes in photosynthetic $\mathrm{CO}_{2}$ flux in arctic ecosystems?, J. Ecol., 95, 139-150, doi:10.1111/j.1365-2745.2006.01187.x, 2007.

Sturm, M., Racine, C., and Tape, K.: Climate change. Increasing shrub abundance in the Arctic, Nature, 411, 546-547, doi:10.1038/35079180, 2001.

Tang, R. L., Li, Z. L., Jia, Y. Y., Li, C. R., Sun, X. M., Kustas, W. P., and Anderson, M. C.: An intercomparison of three remote sensing-based energy balance models using Large Aperture Scintillometer measurements over a wheat-corn production region, Remote Sens. Environ., 115, 3187-3202, doi:10.1016/j.rse.2011.07.004, 2011.

Tanner, C. B. and Jury, W. A.: Estimating evaporation and transpiration from a row crop during incomplete cover, Agron. J., 68, 239-242, 1976.

Timmermans, W. J., Kustas, W. P., Anderson, M. C., and French, A. N.: An intercomparison of the Surface Energy Balance Algorithm for Land (SEBAL) and the Two-Source Energy Balance 
(TSEB) modeling schemes, Remote Sens. Environ., 108, 369384, doi:10.1016/j.rse.2006.11.028, 2007.

Trochim, E. D., Jorgenson, M. T., Prakash, A., and Kane, D. L.: Geomorphic and biophysical factors affecting water tracks in northern Alaska, Earth and Space Science, 3, 123-141, doi:10.1002/2015ea000111, 2016.

Twine, T. E., Kustas, W. P., Norman, J. M., Cook, D. R., Houser, P. R., Meyers, T. P., Prueger, J. H., Starks, P. J., and Wesely, M. L.: Correcting eddy-covariance flux underestimates over a grassland, Agr. Forest Meteorol., 103, 279-300, doi:10.1016/S01681923(00)00123-4, 2000.

Vinukollu, R. K., Sheffield, J., Wood, E. F., Bosilovich, M. G., and Mocko, D.: Multimodel Analysis of Energy and Water Fluxes: Intercomparisons between Operational Analyses, a Land Surface Model, and Remote Sensing, J. Hydrometeorol., 13, 3-26, doi:10.1175/2011JHM1372.1, 2012.

Vörösmarty, C. J., Hinzman, L. D., Peterson, B. J., Bromwich, D. H., Hamilton, L. C., Morison, J., Romanovsky, V. E., Sturm, M., and Webb, R. S.: The Hydrologic Cycle and its Role in Arctic and Global Environmental Change: A Rationale and Strategy for Synthesis Study, Fairbanks, Alaska, 84 pp., 2001.

Webb, E. K., Pearman, G. I., and Leuning, R.: Correction of Flux Measurements for Density Effects Due to Heat and Water-Vapor Transfer, Q. J. Roy. Meteor. Soc., 106, 85-100, doi:10.1002/qj.49710644707, 1980.

Westermann, S., Lüers, J., Langer, M., Piel, K., and Boike, J.: The annual surface energy budget of a high-arctic permafrost site on Svalbard, Norway, The Cryosphere, 3, 245-263, doi:10.5194/tc3-245-2009, 2009.

Williams, M., Street, L. E., van Wijk, M. T., and Shaver, G. R.: Identifying differences in carbon exchange among arctic ecosystem types, Ecosystems, 9, 288-304, doi:10.1007/s10021-005-0146y, 2006.

Williamson, S. N., Barrio, I. C., Hik, D. S., and Gamon, J. A.: Phenology and species determine growing-season albedo increase at the altitudinal limit of shrub growth in the sub-Arctic, Glob. Change Biol., 22, 3621-3631, doi:10.1111/gcb.13297, 2016.
Wilson, K., Goldstein, A., Falge, E., Aubinet, M., Baldocchi, D., Berbigier, P., Bernhofer, C., Ceulemans, R., Dolman, H., Field, C., Grelle, A., Ibrom, A., Law, B. E., Kowalski, A., Meyers, T., Moncrieff, J., Monson, R., Oechel, W., Tenhunen, J., Williams, M., Rastetter, E. B., Shaver, G. R., Hobbie, J. E., Carpino, E., and Kwiatkowski, B. L.: Primary production of an arctic watershed: An uncertainty analysis, Ecol. Appl., 11, 1800-1816, doi:10.1890/10510761(2001)011[1800:PPOAAW]2.0.CO;2, 2001.

Wolf, A., Saliendra, N., Akshalov, K., Johnson, D. A., and Laca, E.: Effects of different eddy covariance correction schemes on a energy balance closure and comparisons with the modified Bowen ratio system, Agr. Forest Meteorol., 148, 942-952, doi:10.1016/j.agrformet.2008.01.005, 2008.

Xu, L., Myneni, R. B., Chapin, F. S., Callaghan, T. V., Pinzon, J. E., Tucker, C. J., Zhu, Z., Bi, J., Ciais, P., Tommervik, H., Euskirchen, E. S., Forbes, B. C., Piao, S. L., Anderson, B. T., Ganguly, S., Nemani, R. R., Goetz, S. J., Beck, P. S. A., Bunn, A. G., Cao, C., and Stroeve, J. C.: Temperature and vegetation seasonality diminishment over northern lands, Nature Climate Change, 3, 581-586, doi:10.1038/Nclimate1836, 2013.

Yao, J. M., Zhao, L., Gu, L. L., Qiao, Y. P., and Jiao, K. Q.: The surface energy budget in the permafrost region of the Tibetan Plateau, Atmos. Res., 102, 394-407, doi:10.1016/j.atmosres.2011.09.001, 2011.

Zhang, K., Kimball, J. S., Nemani, R. R., and Running, S. W.: A continuous satellite-derived global record of land surface evapotranspiration from 1983 to 2006, Water Resour. Res., 46, W09522, doi:10.1029/2009wr008800, 2010.

Zhang, Z., Kane, D. L., and Hinzman, L. D.: Development and application of a spatially-distributed Arctic hydrological and thermal process model (ARHYTHM), Hydrol. Process., 14, 10171044, 2000.

Zhuang, Q., Romanovsky, V. E., and McGuire, A. D.: Incorporation of a permafrost model into a large-scale ecosystem model: Evaluation of temporal and spatial scaling issues in simulating soil thermal dynamics, J. Geophys. Res.-Atmos., 106, 33649-33670, doi:10.1029/2001jd900151, 2001. 